\title{
Neutral Bis(imino)-1,4-dihydropyridinate and Cationic Bis(imino)pyridine $\sigma$-Alkylzinc(II) Complexes as Hydride Exchange Systems: Classic Organometallic Chemistry Meets Ligand-Centered, Biomimetic Reactivity.
}

\author{
John J. Sandoval, Eleuterio Álvarez, Pilar Palma, Antonio Rodríguez-Delgado* and \\ Juan Cámpora*. \\ Instituto de Investigaciones Químicas, CSIC - Universidad de Sevilla. c/ Américo Vespucio, 49, 41092, Sevilla, Spain.
}

\begin{abstract}
The 1,4-dihydropyridinate complex [(4-Bn-HBIP) $\mathrm{Zn}(\mathrm{Bn})]$, readily available through the highly selective reaction of a 2,6bis(imino)pyridine ligand with dibenzylzinc, contains two distinct reactive centers. One of them is the $\sigma$-organometallic benzylzinc moiety, which reacts with weak protic acids (e. g., water or methanol) to release the dihydropyridine ligand free. In contrast, the reaction with $p$-tolualdehyde, a mild electrophile, does not involve the benzylzinc but the 1,4-dihydropyridinate fragment. Even a strong electrophile as $\mathrm{B}\left(\mathrm{C}_{6} \mathrm{~F}_{5}\right)_{3}$ selectively removes the hydrogen atom from the $\mathrm{C} 4$ position of the heterocyclic ring but leaves intact the organometallic fragment, to afford

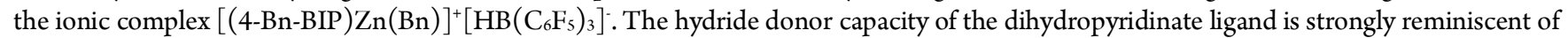
the widespread pyridine-based cofactors (e. g. $\mathrm{NADH} / \mathrm{NAD}^{+}$), one of the most common redox exchange molecules in biologic chemistry. In order to investigate the reversibility of the hydride exchange, we developed an efficient methodology to prepare a family of alkylzinc cations $\left[\left(4-\mathrm{R}^{1}-\mathrm{BIP}\right) \mathrm{Zn}(\mathrm{R})\right]^{+}\left(\mathrm{R}^{1}=\mathrm{H}\right.$ or $\mathrm{Bn} ; \mathrm{R}=\mathrm{Bn}, \mathrm{CH}_{2} \mathrm{SiMe}_{3}$ or neophyl $)$ as salts of the inert tetraarylborate $\left.\operatorname{anion}^{-} \mathrm{BAr}_{4}\right]^{-}\left(\mathrm{Ar}^{\mathrm{F}}=3,5-\mathrm{C}_{6} \mathrm{H}_{3}\left(\mathrm{CF}_{3}\right)_{2}\right)$, based on the reaction of zinc dialkyls $\mathrm{ZnR}_{2}$ with protonated ligands $\left[\mathrm{H}\left(4-\mathrm{R}^{1}-\mathrm{BIP}\right)\right]^{+}\left[\mathrm{BAr}{ }_{4}\right]^{-}\left(\mathrm{R}^{1}=\mathrm{H}\right.$ or $\left.\mathrm{Bn}\right)$. However, the reaction of cationic BIP-organozinc complexes with the hydridic reductant $\mathrm{Na}\left[\mathrm{HBEt}_{3}\right]$ does not revert to the corresponding electroneutral dihydropyridinate derivatives, but causes irreversible release of the tridentate BIP ligands, recovered as stable sodium complexes. The crystal structures of two representative members of the $\left[\left(4-\mathrm{R}^{1}-\mathrm{BIP}\right) \mathrm{Zn}(\mathrm{R})\right]^{+}$family show the $\mathrm{Zn}$ center in a flattened coordination environment, midway between tetrahedral and square planar, that leaves room for the coordination of additional ligands along the direction normal to the mean coordination plane. This relatively open geometry may be enhancing the Lewis acidity at the metal center, driving the selectivity of the reaction with hydride donors to the metal unit in detriment of ligand-centered reactivity.
\end{abstract}

\section{Introduction}

In the last two decades, the chemistry of 2,6-bisiminopyridines (BIP) and their metal complexes has never ceased to attract much interest. ${ }^{1}$ When Brookhart and Gibson reported that iron and cobalt complexes containing BIP ligands gave rise to highly active ethylene polymerization catalysts, ${ }^{2}$ few would have anticipated the potential of the seemingly conventional BIP ligands. Far from behaving as passive spectator ligands, BIPs have a rich chemistry of their own, giving rise to characteristic reactivity patterns. ${ }^{3}$ A salient property of BIP ligands is their non-innocent redox character, i.e., their ability to undergo reversible redox processes, more or less independent of the metal center. ${ }^{4}$ Owing to this property, BIP complexes often exhibit anomalous redox properties, at times incongruent with the usual chemistry of the metal ion involved. For instance, Chirik has shown that $\mathrm{Fe}(\mathrm{II})$ complexes with BIP ligands can be reduced to " $\mathrm{Fe}(0)$ " dinitrogen derivatives like $\left[(\mathrm{BIP}) \mathrm{M}\left(\mathrm{N}_{2}\right)_{\mathrm{n}}\right](\mathrm{n}=1$ or 2$)$. These undergo oxidative addition reactions of organic electrophiles, ${ }^{5}$ atypical in organoiron chemistry. However, rather than low-valent compounds, the electronic structure the reduced species is more appropriately described as $\mathrm{M}$ (II) complexes containing a doubly reduced $\mathrm{BIP}^{2-}$ ligand, and therefore it is the latter which supports the redox change. ${ }^{6}$ In the words of the same author, the ability of BIP ligands to undergo reversible redox processes bestows "nobility" on the BIP-
Fe ensemble, enabling such complexes to catalyze reactions such as hydrogenation, hydrosilylation or C-C coupling, that usually require precious metal-based catalysts.,

The non-innocent behavior of BIP ligands is even more remarkable in their complexes with redox inactive metal ions, i. e., those that have a single oxidation state. A considerable number of reduced complexes of zinc, aluminum, etc. with BIP ligands have been reported in recent years. ${ }^{9}$ Because these metals are abundant and nontoxic, the capacity of their BIP complexes to undergo reversible redox processes is generating great expectations regarding potential uses in catalysis. ${ }^{10}$ These gained support with recent reports by Berben on formally monovalent hydrides, $[(\mathrm{BIP}) \mathrm{Al}(\mathrm{H})]$ that catalyze hydrogen transfer reactions, like the dehydrogenative coupling of amines ${ }^{11}$ and the decomposition of formic acid into $\mathrm{CO}$ and $\mathrm{H}_{2}{ }^{12}$ Mechanistic studies that suggest that, in these reactions, $\mathrm{H}$ transfer steps are facilitated by metal-ligand cooperative relationships developing at different levels. ${ }^{13}$ Thus, the role of the ligand is not limited to act as a non-innocent redox buffer, but it also participates actively in the splitting of X-H bonds, and the subsequent elimination of the $\mathrm{H}$ atoms as dihydrogen. ${ }^{14}$ Furthermore, in the formic acid dehydrogenation reaction, one of the imino groups of the BIP ligands is transformed into an amino donor group, which enables $\beta$-hydrogen elimination through an outer-sphere mechanism. ${ }^{12}$ 
Berben's proposal illustrates how the characteristic reactivity of BIP ligands can give rise to new types of cooperative behavior, that may involve structural modification of the BIP framework. As a matter of fact, a number of fundamental alterations of the structure of BIP ligands have been observed when these ligands interact with organometallic compounds. ${ }^{3}$ Among such processes, alkyl transfer to the remote position $\mathrm{C} 4$ of the BIP pyridine unit is relatively frequent, as shown in Scheme 1. This leads to a modified BIP ligand containing a 4-alkyl-1,4-dihydropyridinate moiety (henceforth 4-R-HBIP, see species A). Complexes of this type are in general very reactive, as the alkylation of $\mathrm{C} 4$ deprives the heterocyclic fragment of its aromatic stabilization. Thus, intermediates of type $\mathbf{A}$ experience further transformations leading to chemical structures such as $\mathbf{B}, \mathbf{C}$ or $\mathbf{D}$. The preference for one or other specific pathway depends on a subtle balance between steric effects in the ligands, the type of group being transferred and the nature of the metal center.

The earliest example of alkyl migration to $\mathrm{C} 4$ was provided by Gambarotta, who reported the isolation of a chromium derivative of a dimeric complex of type $\mathbf{B}$ from the reaction of $\left[\left({ }^{\mathrm{iPr}} \mathrm{BIP}\right) \mathrm{CrCl}_{3}\right]$ (the superscript is a conventional abbreviation for $\mathrm{Ar}=2,6$-diisopropylphenyl) with
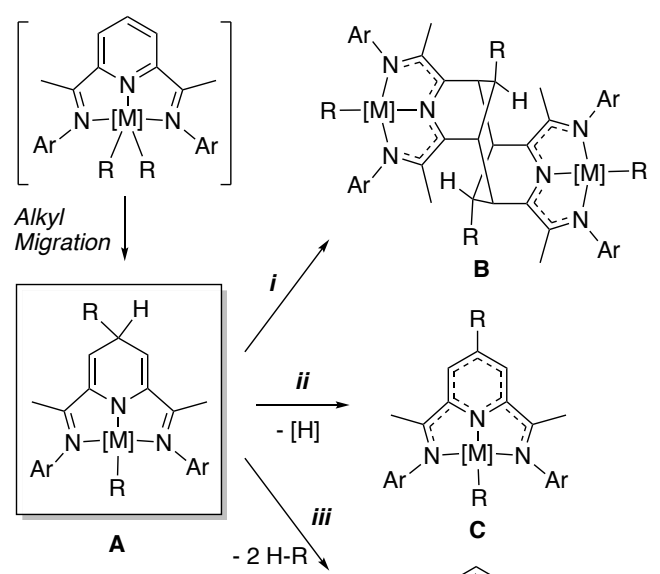

Thermally stable if $[\mathrm{M}]=\mathrm{ZnR}$ or $\mathrm{MgR}$ and $\mathrm{R}=\mathrm{CH}_{2} \mathrm{Ph}$

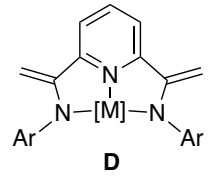

Scheme 1. Reaction pathways triggered by alkyl (R) migration to pyridine $\mathrm{C} 4$ of BIP ligands coordinated to different organometallic fragments. $[\mathrm{M}]:$ i) Dimerization ([M] = Cr, Al-R); ii) Spontaneous hydrogen loss $([\mathrm{M}]=\mathrm{Mn})$; iii) Imine methyl deprotonation $([\mathrm{M}]=\mathrm{Ca}, \mathrm{Sr}$, $\mathrm{Ba})$.

$\mathrm{Mg}\left(\mathrm{CH}_{2} \mathrm{Ph}\right) \mathrm{Cl}^{15}$ The formation of this product was attributed to the dimerization of an undetected intermediate of type $\mathbf{A}$ (path $i$ ). Years ago, we discovered that organomanganous 4-alkyl-1,4-dihydropyridinate complexes of type $\mathbf{A}$, cleanly generated in situ reacting BIP ligands with pre-formed manganese dialkyls $\left[\mathrm{MnR}_{2}\right]_{\mathrm{n}}$ or $\left[\mathrm{MnR}_{2}(\mathrm{THF})\right]_{2}\left(\mathrm{R}=\mathrm{CH}_{2} \mathrm{CMe}_{2} \mathrm{Ph}, \mathrm{CH}_{2} \mathrm{Ph}\right.$, allyl or $\left.\mathrm{CH}_{2} \mathrm{SiMe}_{3}\right),{ }^{16}$ slowly undergo spontaneous dehydrogenation to formally " $\mathrm{Mn}(\mathrm{I})$ " 4-alkyl-BIP complexes, C (route ii). More recently, we have shown that trace amounts of oxygen suffice to trigger the dimerization pathway also in this system, leading to the corresponding $\mathrm{Mn}$ (II) dimers of type $\mathbf{B} .{ }^{17}$ Alkyl migration to the pyridine ring has also been observed when BIP ligands react with organometallic derivatives of "non-redox" main group metals. For example, Budzelaar showed that the reaction of alkylaluminum derivatives with ${ }^{\mathrm{iPr}} \mathrm{BIP}$ produces complicated mixtures arising from non-selective alkyl migration, amongst which the corresponding C4-alkylated products of type $\mathbf{A}$ were detected. ${ }^{18}$ Even though these were unambiguously identified by their NMR spectra, their isolation was prevented by the low selectivity of such reactions. Yet, it was demonstrated that $\mathrm{Al}$ (III) compounds of type A slowly undergo path $i$ and, in two favorable cases, this led to the isolation of crystals and structural authentication of sparingly soluble dimers of type B. Nucleophilic alkylation of BIPs has also been observed in their reactions with polar organometallic derivatives of electropositive metals. ${ }^{19}$ The modified BIP ligands may involve proton abstraction, as outlined in the route (iii) of Scheme 1. Hill has shown that a series of alkali-earth dialkyls $\left[\mathrm{MR}_{2}(\mathrm{THF})_{\mathrm{n}}\right]\left(\mathrm{R}=\mathrm{CH}\left(\mathrm{SiMe}_{3}\right)_{2}, \mathrm{M}=\mathrm{Mg}, \mathrm{Ca}, \mathrm{Sr}, \mathrm{Ba}\right)$ react with ${ }^{\mathrm{iPr}} \mathrm{BIP}$ affording a mixture of regioisomeric intermediates arising from competitive alkylation of the pyridine ring at positions $\mathrm{C} 4$ (type A) and $\mathrm{C} 3 .{ }^{20}$ For the sake of simplicity, the latter is not shown in the scheme but, on heating, both intermediates evolve in parallel undergoing double alkane loss, to afford bis-enamidates of type $\mathbf{D}$. Similarly, our group found that an irresoluble mixture of C-4 and C3 alkylated regiosiomers is formed in the reaction of $\mathrm{Mg}\left(\mathrm{CH}_{2} \mathrm{Ph}\right)_{2}(\mathrm{THF})_{2}$ with BIP ligands, although these proved thermally quite robust and do not experience proton abstraction processes. ${ }^{21}$ Likewise, the reaction of dibenzylzinc or diallylzinc with BIPs, also proceeds with quantitative alkyl transfer to the pyridine ring except that in this case the migration step takes place exclusively at $\mathrm{C} 4{ }^{22}$ This allowed for the first time the isolation of diamagnetic and thermally stable organozinc derivatives with a 2,6-diimino-1,4dihydropyridinate ligand, well suited for reactivity studies. ${ }^{23}$

Several indirect evidences, for example the spontaneous dehydrogenation observed in the $\mathrm{Mn}$ (II) systems, ${ }^{16}$ suggest that dihydropyridinate complexes arising from alkyl transfer to BIP complexes might act as hydrogen donors or even hydridic reductants. In living organisms, the reversible pyridine/dihydropyridine system is integrated in the ubiquitous NAD-based cofactors (e. g., $\left.\mathrm{NAD}^{+} / \mathrm{NADH}\right){ }^{24}$ These co-factors are key pieces in many important metabolic routes, as they provide proton-coupled redox functionality to enzymes, like $\mathrm{Zn}$-containing alcohol dehydrogenase $(\mathrm{LADH}) .{ }^{25}$ Dihydropyridine derivatives have been implemented in biomimetic catalysts, either as ligand ${ }^{26}$ or as environmentally benign substrates in artificial systems. ${ }^{27}$ However, the capacity of dearomatized BIP ligands to act as hydridic reductants remains yet to be demonstrated. ${ }^{28}$ In this context, the availability of a selective route to stable, diamagnetic $\mathrm{Zn}$ (II) dihydropyridinate complexes of type $\mathbf{A}^{22}$ provides a unique opportunity to explore the reactivity of this class of compounds. In this contribution, we show that zinc bisimino-1,4-dihydropyridinate complexes behave as mild hydride donors and, at least in certain cases, that the hydride transfer reaction restores the aromaticity of the pyridine ring, affording cationic organozinc-BIP complexes. In the course of this investigation, we developed a general route to such organozinc derivatives that provides a general entry to $\sigma-$ organozinc-BIP complexes. This method furnished us with the tools required to continue our investigation, exploring the possible use of the multi-faceted chemistry of BIP ligands in processes involving hydrogen transfer reactions.

\section{RESULTS AND DISCUSSION}

As mentioned, we have previously shown that dibenzylzinc reacts with ${ }^{\mathrm{iPr}} \mathrm{BIP}$, selectively affording complex 1 , a 1,4-dihydropyridinate product of type $\mathbf{A}^{22}$ This compound was isolated in good yield as a 
deep blue crystalline solid. In contrast with its highly reactive $\mathrm{Mn}$ (II) analogue, ${ }^{16}$ compound $\mathbf{1}$ is fairly stable in solution at the room temperature. NMR monitoring in $\mathrm{C}_{6} \mathrm{D}_{6}$ or $\mathrm{CD}_{2} \mathrm{Cl}_{2}$ solution over extended periods of time did not reveal any spontaneous transformations like those shown in Scheme 1. However, compound 1 reacts readily with weak acids and electrophiles, as summarized in Scheme 2. We have shown before that methanol attacks at the $\mathrm{Zn}$ center, ${ }^{17}$ cleanly releasing the known 1,4-dihydropyridine base 4-Bn$\mathrm{H}_{2}{ }^{\mathrm{iPr}} \mathrm{BIP}$. In situ NMR investigation of a similar reaction of 1 with $\mathrm{BnOH}$ in $\mathrm{C}_{6} \mathrm{D}_{6}$ in nearly $1: 1$ ratio revealed that the $\mathrm{Zn}$-bound benzyl group ends up as toluene but did not allow to ascertain the fate of the $\mathrm{Zn}$ atom. This is probably lost as an insoluble zinc alkoxide. Next, we tested the ability of $\mathbf{1}$ to react with mild hydride acceptor electrophiles in $\mathrm{C}_{6} \mathrm{D}_{6}$ solution. No changes were observed in the ${ }^{1} \mathrm{H}$ NMR spectrum of 1 when it was treated with equimolar amounts of aldehydes ( $p$-tolualdehyde) or esters (ethyl benzoate or phenyl acetate) at the room temperature. However, when the sample containing $p$ tolualdehyde was heated at $60{ }^{\circ} \mathrm{C}$ for $5 \mathrm{~h}$, the signals of 1 were replaced by those of the free, aromatized ligand 4-Bn- ${ }^{\mathrm{iPr}} \mathrm{BIP}$. Signal integration indicated that this transformation is essentially quantitative. Very likely, the dihydropyridinate complex acts as a hydridic reductant with the aldehyde, but the resulting product decomposes, probably releasing the metal fragment as an alkoxo-metal species and leaving the oxidized, pyridine-containing ligand in solution. The ester substrate PhOAc proved harder to reduce by 1 . After heating for two days at the same temperature, the ${ }^{1} \mathrm{H}$ NMR spectrum showed that most of the starting complex 1 remained in the solution, although some decomposition was already noticeable at this time.

Seeking more informative transformations, we investigated the reaction of 1 with a stronger hydride acceptor. When a solution of 1 in $\mathrm{CD}_{2} \mathrm{Cl}_{2}$ was treated with an equivalent amount of $\mathrm{B}\left(\mathrm{C}_{6} \mathrm{~F}_{5}\right)_{3}$ at the room temperature, an instantaneous color change took place, from dark violet to red. The ${ }^{1} \mathrm{H}$ NMR spectrum of the solution showed that the starting material was cleanly converted into a single product, 2 (see Scheme 2 and Figure 1). Although this compound was not isolated, a complete set of high quality multinuclear NMR spectra, including homo- and heteronuclear 2D correlations were recorded. Full assignment of the ${ }^{1} \mathrm{H}$ and ${ }^{13} \mathrm{C}$ NMR spectra of 2 led to its unambiguous identification as a cationic $\sigma$-alkylzinc species. This is substantiated by the observation of the resonances corresponding to the Zn-bound benzyl fragment, in positions that are essentially unchanged with regard to those of 1 . The ${ }^{1} \mathrm{H}$ and ${ }^{13} \mathrm{C}$ signals of the methylene are observed at $\delta 1.68$ and $18.9 \mathrm{ppm}$, respectively, while their counterparts in 1 are at 1.52 and $19.2 \mathrm{ppm}$. Similar conclusions can be drawn from the signals of the $\mathrm{CH}_{2} \mathrm{Ph}$ phenyl group, a multiplet and a doublet (relative intensities 3:2) within the otherwise clean $5.5-6.5$ ppm region. As can be readily seen in Figure 1, the position and appearance of these signals changes very little on going from 1 to 2 . The aromatic protons show characteristic upfield shifts that originate in the magnetic screening influence of the $N$-aryl rings that are flanking the $\mathrm{Zn}$-bound alkyl. ${ }^{22}$ The almost identical appearance of the alkyl signals in the ${ }^{1} \mathrm{H}$ NMR spectra of $\mathbf{1}$ and $\mathbf{2}$ not only confirms that the $\sigma$-alkyl group is retained in the latter, but it clearly demonstrates that the coordination environment of $\mathrm{Zn}$ remains approximately square-planar, keeping the $\mathrm{CH}_{2} \mathrm{Ph}$ unit "sandwiched" between the $N$-aryls. Conversely, several ${ }^{1} \mathrm{H}$ resonances corresponding to protons connected to the heterocyclic unit experience most evident changes. Thus, the ${ }^{1} \mathrm{H}$ signals of 1 corresponding to C3- $H$, and to the $\mathrm{CH}_{2}$ of the benzyl substituent at $\mathrm{C} 4$, two doublets at $\delta$
5.31 and 2.85 ppm, respectively, move more than 3 ppm downfield on going to 2 , and each of them collapses into a singlet. The loss of multiplicity is connected with the disappearance of the resonance of C4- $H$, a characteristic multiplet at $\delta 3.76 \mathrm{ppm}$ in the spectrum of 1 that finds no counterpart for 2 . Such spectral features indicate that $\mathrm{B}\left(\mathrm{C}_{6} \mathrm{~F}_{5}\right)_{3}$ removes the hydrogen atom bound to the dihydropyridine $s p^{3} \mathrm{C} 4$ giving rise to $\left[\mathrm{HB}\left(\mathrm{C}_{6} \mathrm{~F}_{5}\right)_{3}\right]$; as confirmed by the characteristic signals of the hydroborate anion in the ${ }^{11} \mathrm{~B}\left\{{ }^{1} \mathrm{H}\right\}$ and ${ }^{19} \mathrm{~F}\left\{{ }^{1} \mathrm{H}\right\}$ NMR spectra. ${ }^{29}$ To balance the electric charge of the hydroborate, the zinccontaining fragment must be a cation that presently exists in solution as the corresponding salt, $2 \cdot \mathrm{HB}\left(\mathrm{C}_{6} \mathrm{~F}_{5}\right)_{3}$. The identity of cation 2 was confirmed by its independent syntheses as a tetraarylborate salt, as described below (spectrum $\mathrm{C}$ in Figure 1).

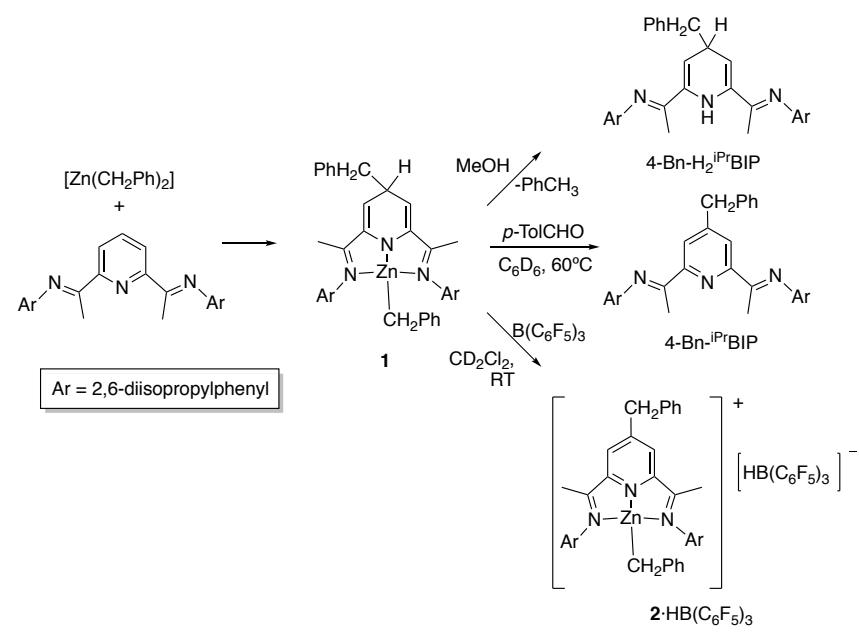

Scheme 2. Some reactions of compound $\mathbf{1}$ with acids and electrophiles.

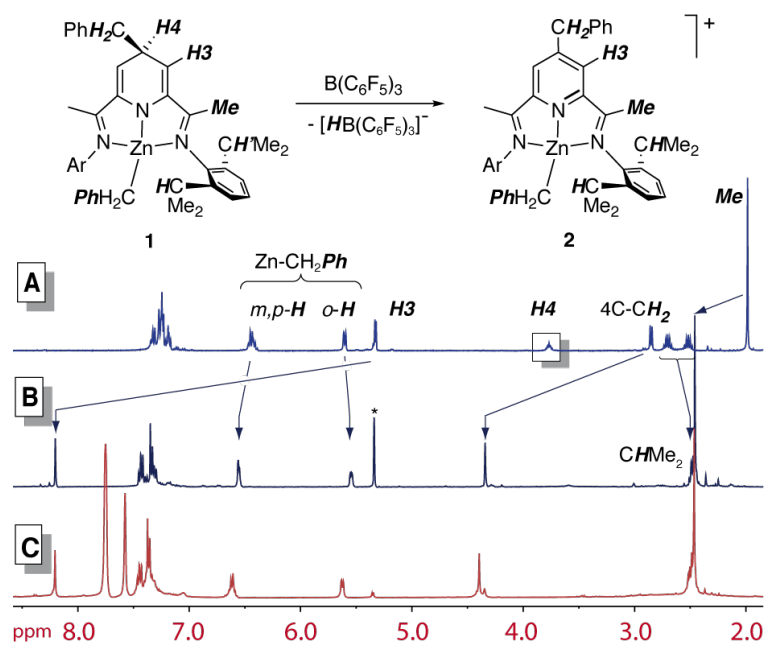

Figure 1. ${ }^{1} \mathrm{H}$ NMR spectra (region 8.5 - $2.0 \mathrm{ppm}$ ) of the of complex 1 (A), and of $2 \cdot \mathrm{HB}\left(\mathrm{C}_{6} \mathrm{~F}_{5}\right)_{3}(\mathrm{~B})$, highlighting the relationships between analogous signals $\left(\mathrm{CD}_{2} \mathrm{Cl}_{2}, 25^{\circ} \mathrm{C}, 400 \mathrm{MHz}\right)$. (C): the spectrum of the cation 2 as a tetraarylborate salt $\left(2 \cdot \mathrm{BAr}_{4}^{\mathrm{F}}\right.$, see below). The signal marked ${ }^{*}$ corresponds to a trace of adventitious $\mathrm{CH}_{2} \mathrm{Cl}_{2}$.

The reactivity pattern outlined in Scheme 2 demonstrates that two potentially reactive centers with markedly different chemical character coexist in the molecule 1 . The organometallic $\mathrm{Zn}-\mathrm{CH}_{2} \mathrm{Ph}$ moiety behaves as a base when confronted with mild protic acids, whilst the 1,4-dihydropyridinate ligand acts as a hydride donor towards 
electrophiles $\left(p\right.$-TolCHO or $\left.\mathrm{B}\left(\mathrm{C}_{6} \mathrm{~F}_{5}\right)_{3}\right)$. The clear-cut contrast between the basic organometallic site and the nucleophilic reactivity of the dihydropyridine is remarkable, as $\mathrm{B}\left(\mathrm{C}_{6} \mathrm{~F}_{5}\right)_{3}$ so readily abstracts alkyl groups by from most $\sigma$-organometallic species, ${ }^{30}$ that this reaction is regularly employed as a catalyst activation method in polymerization chemistry. ${ }^{31}$ Pertinent examples are the activation of iron complex $\left[\left({ }^{\mathrm{iPr}} \mathrm{BIP}\right) \mathrm{Fe}\left(\mathrm{CH}_{2} \mathrm{SiMe}_{3}\right)_{2}\right]$, reported by Chirik, ${ }^{32}$ or dialkylzinc complexes bearing $\alpha$-diimine ligands, investigated by Bochmann, ${ }^{33}$ with $\mathrm{B}\left(\mathrm{C}_{6} \mathrm{~F}_{5}\right)_{3}$. In either case, the products are highly reactive ion pairs $[\mathrm{Ln} M-\mathrm{R}]^{+}\left[\mathrm{R}-\mathrm{B}\left(\mathrm{C}_{6} \mathrm{~F}_{5}\right)_{3}\right]$. It is worth mentioning that Gibson showed ${ }^{19}$ that a zinc complex similar to 2 is formed upon treatment of the $N$-ethylated zinc complex $\left[\left(N\right.\right.$-Et- $\left.\left.{ }^{\mathrm{Me}} \mathrm{BIP}\right) \mathrm{Zn}(\mathrm{Et})\right]$ (here the Ar groups are 2,6-dimethylphenyl, and the BIP is ethylated at the heterocyclic nitrogen) with one equivalent of $\mathrm{B}\left(\mathrm{C}_{6} \mathrm{~F}_{5}\right)_{3}$ in $\mathrm{CD}_{2} \mathrm{Cl}_{2}$. The product was not characterized in detail, but it was suggested to be the ion pair $\left[\left({ }^{\mathrm{Me}} \mathrm{BIP}\right) \mathrm{ZnEt}\right]^{+}\left[\mathrm{Et}-\mathrm{B}\left(\mathrm{C}_{6} \mathrm{~F}_{3}\right)_{3}\right]^{-}$on the basis of a few diagnostic features of its ${ }^{1} \mathrm{H}$ NMR spectrum. This proposal, now supported by the consistency of the published data with those of 2, apparently points to direct electrophilic cleavage of the N-Et bond, presumably favored by the restoration of aromaticity at the heterocycle. However, further work reported in the same article ${ }^{19}$ conclusively demonstrated that the borane actually removes the alkyl group $(\mathrm{R})$ from the metal center, and then the resulting threecoordinated intermediate $\left[\left(N \text {-Et- }{ }^{\mathrm{Me}} \mathrm{BIP}\right) \mathrm{Zn}\right]^{+}\left[\mathrm{R}-\mathrm{B}\left(\mathrm{C}_{6} \mathrm{~F}_{5}\right)_{3}\right]^{-}$rearranges into the stable $\sigma$-organometallic product via ethyl transfer from $\mathrm{N}$ to $\mathrm{Zn}$. The conclusion of this excursion into the literature data is that the selective hydride-donor behavior of the 1,4-dihydropyridine ring of $\mathbf{1}$ in the presence of a potentially competitor like a $\sigma-\mathrm{Zn}-\mathrm{C}$ bond can be regarded as an exceptional feature. The coexistence of a pyridine-based reductant and a coordination fragment containing the biologically relevant $\mathrm{Zn}$ (II) cation $^{34}$ is an interesting coincidence, reminiscent of some widespread redox biocatalysts (e. g., liver alcohol dehydrogenase $\mathrm{e}^{25}$ and other $\mathrm{NADH} / \mathrm{NAD}^{+}$dependant enzymes ${ }^{24}$ ). The possible enhancement of the reducing power of the dihydropyridine unit by a classic organometallic fragment as $\mathrm{Zn}-\mathrm{R}$ is an intriguing possibility. ${ }^{35}$ These considerations encouraged us to pursue our investigation, completing the characterization of the cationic organometallic product $\mathbf{2}$ with a crystal structure determination.

As mentioned before, the high solubility of complex $2 \cdot \mathrm{HB}\left(\mathrm{C}_{6} \mathrm{~F}_{5}\right)_{3}$ prevented the isolation of crystalline samples of this compound suitable for X-ray diffraction. Furthermore, although hydride abstraction by $\mathrm{B}\left(\mathrm{C}_{6} \mathrm{~F}_{5}\right)_{3}$ is very clean and selective, the scope of this method is limited to the few stable precursors of type $\mathbf{A}$ (cf. Scheme 1) available via nucleophilic BIP alkylation reactions. Therefore, we sought an alternative approach to the syntheses of $\sigma$-organozinc cations, like 2, counterbalanced by suitable anions of low coordination capacity, designed to facilitate isolation. In a former contribution, we reported that the reaction of $\mathrm{Mn}$ (II) dialkyl complexes $\left[\mathrm{MnR}_{2} \mathrm{Py}_{\mathrm{n}}\right]$ $(\mathrm{n}=1$ or 2$)$ with the well-defined acidic salt $\left[\mathrm{H}\left({ }^{\mathrm{iPr}} \mathrm{BIP}\right)\right]^{+}\left[\mathrm{BAr}^{\mathrm{F}}\right]^{-}$ $\left(\mathrm{Ar}^{\mathrm{F}}=3,5-\mathrm{C}_{6} \mathrm{H}_{3}\left(\mathrm{CF}_{3}\right)_{2}\right)$ provides an efficient route to cationic $\mathrm{Mn}(\mathrm{II})$ monoalkyls containing the ${ }^{\mathrm{iPr}} \mathrm{BIP}$ ligand. ${ }^{16 \mathrm{~b}}$ Taking advantage of the selective alkylation of BIP ligands that we had developed before, ${ }^{16 a}$ we synthesized the protonated salt $[\mathrm{H}(4-\mathrm{Bn}$ $\left.\left.{ }^{i \mathrm{Pr}} \mathrm{BIP}\right)\right]^{+}\left[\mathrm{BAr}_{4}^{\mathrm{F}}\right]$. Likewise, we prepared the less hindered mesityl derivative $\left[\mathrm{H}\left({ }^{\mathrm{Mes}} \mathrm{BIP}\right)\right]^{+}\left[\mathrm{BAr}_{4}^{\mathrm{F}}\right]$. Both protonated ligands were isolated as orange microcrystalline solids. As expected, their ${ }^{1} \mathrm{HNMR}$ spectra in $\mathrm{CD}_{2} \mathrm{Cl}_{2}$ are similar to those of their neutral precursors, except for the signals of the $\left[\mathrm{BAr}_{4}{ }_{4}\right]$ and the acidic proton (the latter at ca. $11 \mathrm{ppm}$ as a characteristic broad resonance). The invariance of the ${ }^{19} \mathrm{~F}\left\{{ }^{1} \mathrm{H}\right\}$ and ${ }^{11} \mathrm{~B}\left\{{ }^{1} \mathrm{H}\right\}$ resonances of the anion over extensive periods of time demonstrates that these reagents can be handled solution without decomposition.

In order to establish the scope and selectivity of the $\mathrm{Zn}-\mathrm{C}$ cleavage reactions with the protonated BIP ligands, we investigated all nine possible combinations of each protonated ligand with each one out of a set of three zinc dialkyls $\left(\mathrm{R}=\mathrm{CH}_{2} \mathrm{Ph}, \mathrm{CH}_{2} \mathrm{CMe}_{2} \mathrm{Ph}\right.$ or $\mathrm{CH}_{2} \mathrm{SiMe}_{3}$ ) in 1:1 stoichiometric ratio, as shown in Scheme 3. Independently of the nature of the R group or the substitution pattern at the BIP ligand, NMR analyses of the crude reaction mixtures showed that these reactions proceed with complete selectivity to afford a single product. Double $\mathrm{Zn}-\mathrm{C}$ cleavage did not take place at any significant extent, although dications $\left[\mathrm{Zn}(\mathrm{BIP})_{2}\right]^{2+}$ are known to be stable. ${ }^{36}$ In some cases, we found convenient to use of a slight excess of the zinc dialkyl precursor for practical reasons, as this is readily separated from the solid products. The targeted complexes $(2-10)$ were obtained as analytically pure orange or yellow-orange solids after a simple workup. They were fully characterized with spectroscopic and analytical techniques (elemental analysis, IR, ${ }^{1} \mathrm{H}$ and ${ }^{13} \mathrm{C}\left\{{ }^{1} \mathrm{H}\right\}$ NMR and ESI-MS). In each case, the ${ }^{1} \mathrm{H}$ NMR spectrum would suffice to demonstrate that the expected cationic monoalkylzinc derivative has been formed. For example, the ${ }^{1} \mathrm{H}$ NMR spectrum of $2 \cdot \mathrm{BArF} 4$, shown in Figure 1 (C), is essentially the same as that of $2 \cdot \mathrm{HB}\left(\mathrm{C}_{6} \mathrm{~F}_{5}\right)_{3}(\mathrm{~B}$, in the same figure $)$, except for the tetraarylborate resonances.

The predictable selectivity and straightforward outcome of these reactions provides for the first time a robust and reliable route to organozinc complexes supported by electroneutral BIP ligands. Our efforts to isolate crystalline samples were finally rewarded for complexes 6 and 10, which crystallized from cold $\left(-20^{\circ} \mathrm{C}\right) \mathrm{Et}_{2} \mathrm{O} /$ hexane or $\mathrm{Et}_{2} \mathrm{O}$ /pentane mixtures. The structures of the cationic fragments can be seen in Figures 2 and 3, and selected bond lengths and angles are listed in the corresponding captions. Both complexes exhibit very similar features. The average lengths of the imino $\mathrm{C}=\mathrm{N}$ and the $\mathrm{C}-\mathrm{C}$ bonds within the BIP units are unexceptional and fully consistent with electroneutral, or "innocent" ligands. ${ }^{3 b, 37}$ In consequence, the oxidation state of $\mathrm{Zn}$ can be unambiguously assigned as +2 . The planar BIP ligand enforces a flat geometry of the $\mathrm{Zn}$ center that looks, at first glance, as distorted square-planar. This is quite unusual for $\mathrm{Zn}$ (II) that, with a complete $3 d^{10}$ shell, lacks geometrical preferences. Most often, this ion favors even distribution of the ligands in the surrounding space, usually approaching tetrahedral geometry for coordination number 4 . The $\tau_{4}{ }^{\prime}$ parameter, an improved quantitative descriptor of tetra-coordinated geometry, is 0.50 for 6 and 0.48 for 10. These confirm that the coordination environment is slightly closer to square planar $\left(\tau_{4}{ }^{\prime}=0\right)$ than tetrahedral $\left(\tau_{4}{ }^{\prime}=1\right)$, but less than in the previously reported structure of $1^{22}\left(\tau_{4^{\prime}}=0.24\right)$. Still, in both 6 and 10 the $\mathrm{Zn}-\mathrm{C}$ bond deviates severely from the ideal square coordination, pointing "upwards" from the mean coordination plane. The angle formed by the $\mathrm{Zn}-\mathrm{N} 1$ (pyridine) and $\mathrm{Zn}-\mathrm{C}$ bonds can be used to gain an intuitive measure of this distortion. This ought to be flat $\left(180^{\circ}\right)$ in ideal planar geometry but reduces its span down to $\mathrm{ca} .155^{\circ}$ in both complexes. The configuration of the alkyl groups is the same observed in isostructural transition metal monoalkyls of composition $\left[(\mathrm{BIP}) \mathrm{M}\left(\mathrm{CH}_{2} \mathrm{EMe}_{3}\right)\right]^{\mathrm{n}+}\left(\mathrm{M}=\mathrm{Mn},{ }^{15 \mathrm{a}, 39} \mathrm{Fe}^{32,40,41}\right.$ or $\mathrm{Co}^{42} ; \mathrm{E}=\mathrm{Si}$ or $\left.\mathrm{C}\right)$, regardless of their charge $(n=1,0$ or -1$)$. Although this kind of arrangement is sometimes reported as distorted square planar, ${ }^{40}$ it would be more accurately described as a flattened tetrahedron to account for the noticeable deviation of $\mathrm{M}$ out of the plane defined by the BIP ligand (ca. $0.5 \AA$ for 6 and 10). In contrast, 


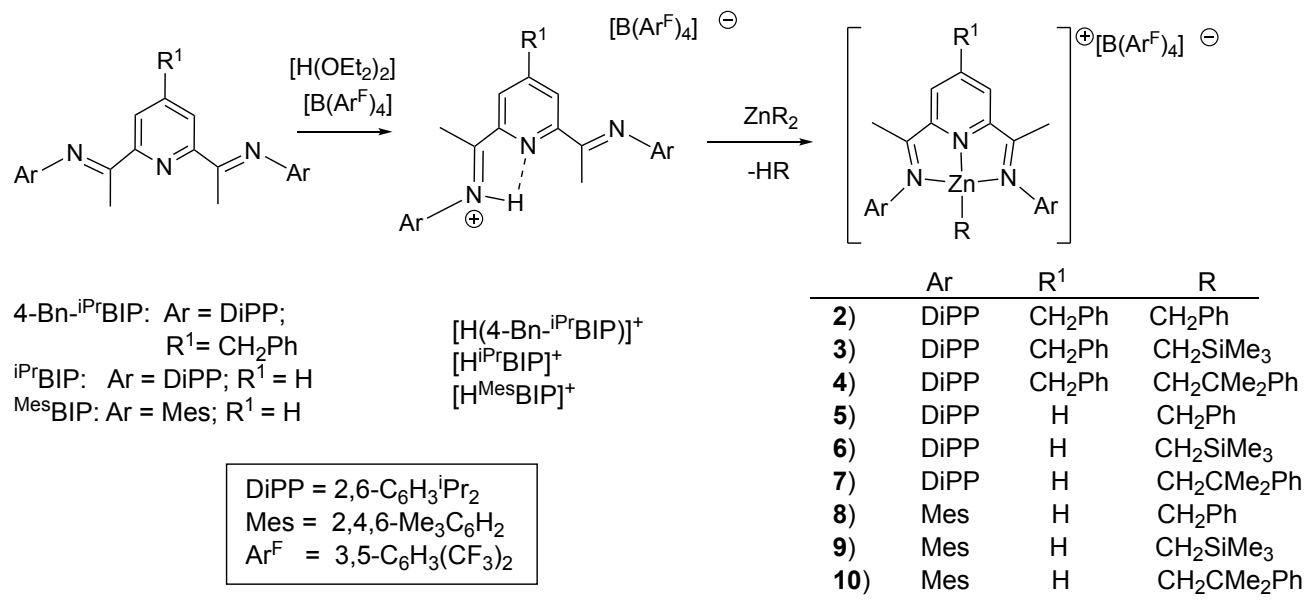

Scheme 3. General syntheses of cationic $\mathrm{Zn}$ (II) alkyl complexes supported with BIP ligands.

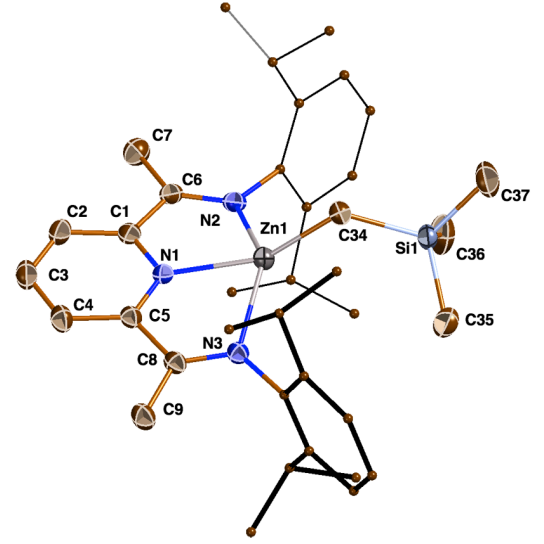

Figure 2. ORTEP plot (40\% probability) of the cationic part of 6. $\mathrm{N}$ Aryl groups have been simplified for clarity. Selected bond distances $(\AA)$ and angles (deg): Zn1-C34 1.952(5); Zn1-N1, 2.057(3); Zn1-N2, 2.277(3); Zn1-N3, 2.299(3); C1-N1, 1.336(4); C5-N1, 1.338(4); C1C6, 1.494(4); C5-C8, 1.487(4); C6-N2, 1.285(4); C8-N3, 1.283(4); C34-Zn1-N1, 152.43(11); N2-Zn1-N3, 141.39(9); N1-Zn1-N2, 74.19(11); N1-Zn1-N3, 73.32(11); Distance from Zn1 to the [N1-N2N3] plane: $0.56 \AA$.

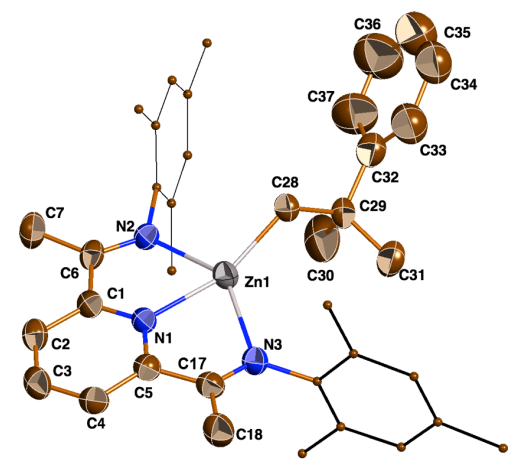

Figure 3. ORTEP plot (40\% probability) of the cationic part of 10. $\mathrm{N}$ Aryl groups have been simplified for clarity. Selected bond distances $(\AA)$ and angles (deg): Zn1-C28 1.970(5); Zn1-N1, 2.069(4); Zn1-N2, 2.367(4); Zn1-N3, 2.243(5); C1-C6, 1.472(8); C5-C17, 1.483(8); C1N1, 1.346(7); C5-N1, 1.337(7); C8-N2, 1.449(7); C17-N3, 1.434(7); C28-Zn1-N1, 158.0(2); N3-Zn1-N2, 141.88(15); N1-Zn1-N2, 72.15(17); N1-Zn1-N3, 74.76(17). Distance from Zn1 to the to the[N1-N2-N3] plane: $0.52 \AA$. a number of crystal structures of similar complexes containing smallsized $\mathrm{X}$ ligands $\left[\left({ }^{\mathrm{iPr}} \mathrm{BIP}\right) \mathrm{M}-\mathrm{X}\right]^{\mathrm{n}+}$ (e. g., $\mathrm{X}=$ halogen or methyl; $\mathrm{M}=$ $\mathrm{Mn},{ }^{39} \mathrm{Fe},{ }^{32,43} \mathrm{Co},{ }^{42 a, 44} \mathrm{Ni}^{45}$ or $\mathrm{Cu}^{46}$; $\mathrm{n}$ varying from -1 to +1 ) all exhibit strictly flat geometries. In other words, in the extensive of series structures available of four-coordinated derivatives of the first transition row with BIP ligands, the geometry of the coordination environment is dictated by the steric interactions of the metal-bound group, rather than the oxidation state of the [(BIP)M] fragment or the $d$-electron count of the central ion. ${ }^{42 a}$ It seems that this conclusion holds also for $\mathrm{Zn}$. Accordingly, Nikonov reported very recently two examples of reduced " $\mathrm{Zn}(\mathrm{I})$ " complexes, $\left[\left({ }^{\mathrm{iPr}} \mathrm{BIP}\right) \mathrm{Zn}(\mathrm{X})\right](\mathrm{X}=$ $\mathrm{Cl}, \mathrm{Me}$ ) with a rigorously flat geometry. ${ }^{\text {aa }}$ It would be also tempting to invoke steric effects to explain why the solid-state structure of $\mathbf{1 0}$ exhibits a notorious disparity in the bonds linking the $\mathrm{Zn}$ center to the terminal imino groups (Zn-N2, 2.367(4); Zn-N3, 2.243(5) A). However, the difference is smaller for 6 (2.277(3) and 2.299(3) $\AA$ ), which, having bulkier substituents on the BIP ligand, would be expected to be even more distorted. Therefore, disparate bond distances are most likely produced by the influence of crystal packing forces on the relatively weak $\mathrm{Zn}-\mathrm{N}$ (imine) bonds. ${ }^{47}$

The flat coordination environment that BIP ligands impose to the $\mathrm{Zn}$ (II) center leaves large unshielded spaces along the axial directions normal to the mean molecular plane. This feature favors the addition of extra ligands to the coordination sphere of $\mathrm{Zn}$ (II), enhancing its Lewis acidic character. Nikonov showed that the abovementioned electroneutral $\mathrm{Zn}(\mathrm{II})$ square-planar complex $\left[\left({ }^{\mathrm{iPr}} \mathrm{BIP}\right) \mathrm{ZnCl}\right]$ captures 4-dimethylaminopyridine (DMAP) as a fifth ligand, forming an isolable adduct with a square-pyramidal $\mathrm{Zn}$ center. We observed that the ${ }^{1} \mathrm{H}$ NMR spectra of cationic $\mathrm{Zn}$ complexes $\mathbf{2}-10$ experience noticeable changes in the presence of potentially binding solvents, such as THF, that can be attributed to similar but reversible interactions of this weak base with the $\mathrm{Zn}$ (II) center. Since Lewis acidity is a crucial property in catalysis, we briefly examined the effect of controlled addition of THF or pyridine on the ${ }^{1} \mathrm{H}$ spectrum of one of the cationic complexes, the (trimethylsilyl)methyl derivative 3, in $\mathrm{CD}_{2} \mathrm{Cl}_{2}$ solution. Successive additions of THF (up to 4 equiv) causes both the resonances of the $\mathrm{Zn}-\mathrm{CH}_{2} \mathrm{Si} M e_{3}$ group to drift from their original positions, whilst the rest of the spectrum remains essentially unchanged. The methylene signal moved upfield $(\Delta \delta=-0.12 \mathrm{ppm})$, whilst that of the $\mathrm{SiMe}_{3}$ experienced a modest shift in the opposite direction $(\Delta \delta=+0.03 \mathrm{ppm}$ at most $)$. Both signals returned to their original positions when the solution was evaporated and the residue dissolved in fresh $\mathrm{CD}_{2} \mathrm{Cl}_{2}$. Addition 
of 1 equivalent of pyridine had more visible effects on the width and positions of nearly every signal in the spectrum of $\mathbf{3}$ (see Figure 4). The shifts of the methylene and $\mathrm{SiMe}_{3}$ signals had the same signs but more pronounced values $(\Delta \delta=-0.27 \mathrm{ppm}$ and $+0.22 \mathrm{ppm}$, respectively) than those induced by THF. In addition, the strong binding of pyridine to 3 is evidenced by the persistence of these spectral changes when the volatile components of the mixture were removed. A mechanistically significant effect is the selective broadening of one of the signals corresponding to a pair of diastereotopic methyls of the isopropyl groups, whilst the other remains as a well-resolved doublet (this is accompanied by the significant broadening of the signal due to the isopropyl methynes, not shown in the figure). This effect can be attributed to the fast exchange of a single pyridine ligand between two chemically equivalent coordination sites available, located above and below to the molecular plane, as suggested in Scheme 4. Note that the rigid disposition of the aryl groups brings one of the methyl in each $i$-Pr closer to the stereogenic center, whilst the other is located at a farther position where the chemical environment is less perturbed by the exchange process. Such square-pyramidal configuration would be the same found in the crystal structure of the analogous $\mathrm{Mn}(\mathrm{II})$ complex $\left[\left({ }^{\mathrm{iPr}} \mathrm{BIP}\right) \mathrm{Mn}\left(\mathrm{CH}_{2} \mathrm{CMe}_{2} \mathrm{Ph}\right)(\mathrm{Py})\right]^{+}$

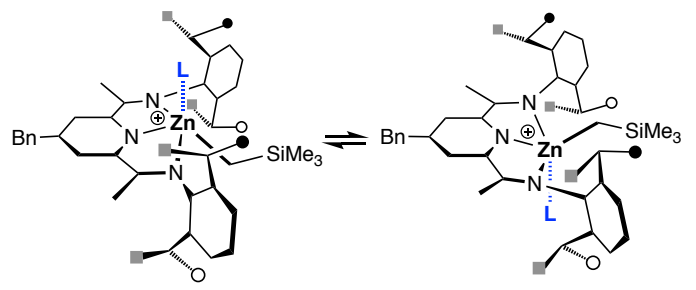

Scheme 4. Inversion of the square-pyramidal adduct of 3 with a monodentate ligand (L), causing the exchange of the iPr-methyl groups placed above and below the pyramid basis (marked with black and hollow circles). Black and hollow circles emphasize the different chemical environments of the methyl groups directed towards the stereogenic center, and less sensitive methyl groups pointing outwards are marked with grey squares.

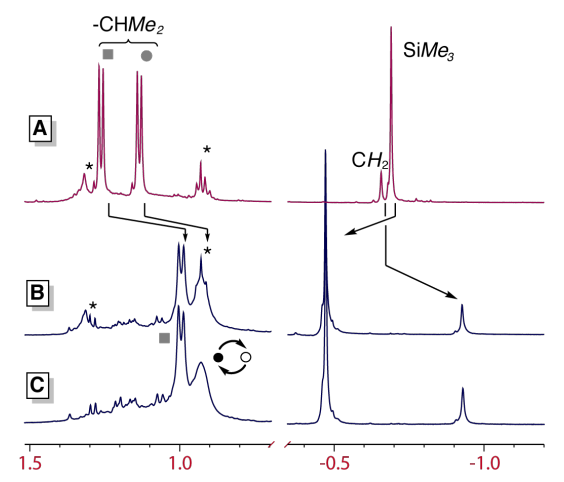

Figure 4. Effect of the addition of one equivalent of pyridine on the ${ }^{1} \mathrm{H}$ NMR spectrum of compound 3 in $\mathrm{CD}_{2} \mathrm{Cl}_{2}$ (only two selected regions are shown). Signals of diastereotopic methyl couples are marked with a square and a circle; signals marked with asterisk denote the presence of small amounts of hexane. Black and hollow circles with an equilibrium arrow indicate the fluxional exchange process depicted in Scheme 4. A) Compound 3. B) After adding 1 equiv. of pyridine at the room temperature. C) The same sample after removal of volatiles in vacuo and dissolved in fresh $\mathrm{CD}_{2} \mathrm{Cl}_{2}$. Note the disappearance of the signals of hexane, but otherwise the spectrum remains essentially unaltered; the broad hump under the $\mathrm{CHMe}$ resonances evidences some decomposition of the sensitive sample during the experiment.
$\left[\mathrm{BAr}_{4}{ }_{4}\right] \cdot{ }^{16 \mathrm{~b}}$ In consequence, it can be reasonably concluded that 3 is a moderately strong Lewis acid that interacts reversibly with weak bases such as THF and forms stable 1:1 adducts with stronger ones, like pyridine.

With an efficient route to cationic alkylzinc complexes in hand, our next step was to explore the reversibility of the hydride abstraction reaction that led us to the discovery of cation 2 , by examining the reactions of cationic alkylzinc complexes with a suitable hydride donor. We felt that the hydroborate anion $\left[\mathrm{HBEt}_{3}\right]^{\prime}$, akin to $\left[\mathrm{HB}\left(\mathrm{C}_{6} \mathrm{~F}_{5}\right)_{3}\right]^{-}$but a powerful hydride source, would be a good choice to reduce cationic complexes like 2 to the corresponding 1,4-dihydropyridinate analogues of 1 . This proposal was supported by the studies by Kundu et al. ${ }^{48}$ on group 10 complexes with the PNP pincer ligand 2,6-bis(di- $t$-butylphosphinito)pyridine ( ${ }^{\mathrm{Bu}} \mathrm{PONOP}$ ) which, like BIPs, has a pyridine ring as the central structural element. These authors reported in 2011 that the reaction of chloro derivatives [ $\left({ }^{\mathrm{B} u}\right.$ PONOP $) \mathrm{M}(\mathrm{Cl})]^{+}(\mathrm{M}=\mathrm{Ni}, \mathrm{Pd}$ or $\mathrm{Pt})$ with $\mathrm{Li}\left[\mathrm{HBEt}_{3}\right]$ affords the corresponding 1,4-dihydropyridinate derivatives arising from hydride transfer to the pyridine, rather than undergoing the usual chloride/hydride exchange. However, the reaction of cations 2 or 5 (both as $\mathrm{BAr}_{4}{ }_{4}$ salts) with $\mathrm{Na}\left[\mathrm{HBEt}_{3}\right]$ takes a different course, as depicted in Scheme 5.

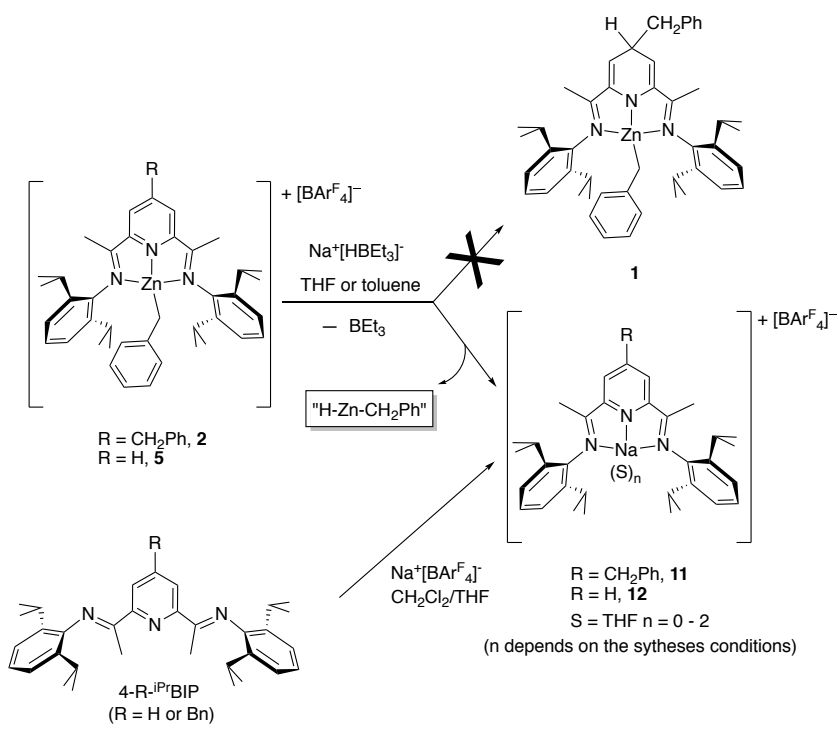

Scheme 5. Reactions of cationic compounds $\mathbf{2}$ and $\mathbf{5}$ with the hydride transfer reagentNa ${ }^{+}\left[\mathrm{HBEt}_{3}\right]$.

When one equivalent of the commercial solution of this reagent in toluene was added to a stirred solution of $2 \cdot \mathrm{BAr}^{\mathrm{F}}{ }_{4}$ in THF at $-60{ }^{\circ} \mathrm{C}$, a distinct color change from orange to bluish-green took place, remarkably different from the intense purple color of $\mathbf{1}$. Different shades of green were observed as the mixture was allowed to warm up to the room temperature, but the color disappeared during the workup, which afforded the pale-yellow product 11 in moderate yield. A similar product was obtained when $\mathrm{Na}\left[\mathrm{HBEt}_{3}\right]$ was slowly added to a toluene suspension of complex 5 which, lacking the benzyl substituent at the pyridine $\mathrm{C} 4$, bears less steric hindrance at this position. No transient colors were observed in this case, but the orange color of the starting material faded gradually to leave a light yellow-colored suspension. Product 12, also a pale-yellow solid, was readily purified by consecutive washings with hexane. Both 11 and 12 are soluble in dichloromethane and THF, and insoluble in hydrocarbon solvents. However, we were unable to grow quality crystals for X-ray diffraction of any of these two products. Their solubility 
properties suggested that both are ionic complexes. Their ${ }^{1} \mathrm{H}$ and ${ }^{13} \mathrm{C}\left\{{ }^{1} \mathrm{H}\right\}$ NMR spectra are different from those of the starting materials $2 \cdot \mathrm{BAr}^{\mathrm{F}}$ and $\mathbf{5}$ but still show one equivalent of $\left[\mathrm{BAr}^{\mathrm{F}}\right.$ ], hence 11 and 12 are 1:1 electrolyte complexes. Both compounds have been identified as cationic sodium complexes of the corresponding BIP ligands, as $\mathrm{BAr}_{4}^{\mathrm{F}}$ salts. The ${ }^{1} \mathrm{H}$ spectrum of $\mathbf{1 1}$ is confronted to that of its parent compound $2 \cdot \mathrm{BAr}^{\mathrm{F}}{ }_{4}$ in Figure 5 . As can be seen, both spectra share in common the typical signals of the aromatic 4-Bn-BIP ligand and $\mathrm{BAr}_{4}{ }_{4}$ but the characteristic high-field resonances of the metal-bound benzyl fragment are lacking in the spectrum of the former. Instead, the spectrum of $\mathbf{1 1}$ exhibits two characteristic multiplets at $\delta 3.25$ and $1.68 \mathrm{ppm}$ assigned to a molecule of THF coordinated to $\mathrm{Na}^{+}$, as these are somewhat shifted upfield (THF in $\mathrm{CD}_{2} \mathrm{Cl}_{2}$ : $\delta 3.69$ and 1.82 ppm, respectively ${ }^{49}$ ). Years ago, Gambarotta and Budzelaar reported the crystal structure of two unusual bimetallic complexes containing a $4-y l^{-}{ }^{\mathrm{iPr}} \mathrm{BIPNa}(\mathrm{THF})_{2}$ moiety $\sigma$-bound at $\mathrm{C} 4$ to a paramagnetic Fe center ${ }^{50}$ but, otherwise, stable coordination complexes of typical BIP ligands with alkali metals heavier than $\mathrm{Li}$ are rare. Thus, in order to confirm the identity of both products, we reacted the corresponding ligands $4-\mathrm{R}-{ }^{\mathrm{iPr}} \mathrm{BIP}(\mathrm{R}=\mathrm{Bn}$ or $\mathrm{H})$ with one equivalent of the salt $\mathrm{Na}^{+}\left[\mathrm{BAr}_{4}{ }^{-}\right.$in $\mathrm{CH}_{2} \mathrm{Cl}_{2}$, in the presence of a small amount of THF. The corresponding products were isolated as rather stable materials, with indistinguishable solubility properties and the same pale-yellow color as $\mathbf{1 1}$ and 12, respectively. For the sake of comparison, Figure 3 displays the ${ }^{1} \mathrm{H}$ NMR spectrum of the product obtained for $\mathrm{R}=\mathrm{Bn}$ derivative which, as can be seen, is virtually identical to that of $\mathbf{1 1}$ except for the fact that this material contains two equivalents of THF. On the other hand, the material prepared from ${ }^{\mathrm{iPr}} \mathrm{BIP}$ was precipitated as a microcrystalline solid from a cold hexane/

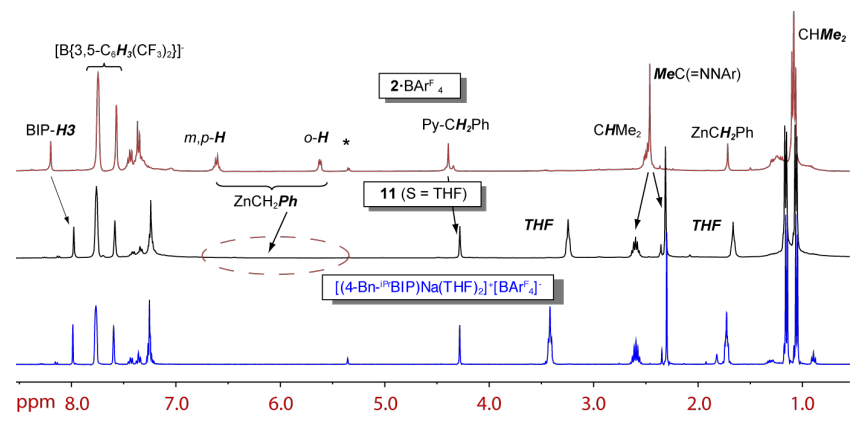

Figure 5. ${ }^{1} \mathrm{H}$ NMR spectra ( $400 \mathrm{MHz}, \mathrm{CD}_{2} \mathrm{Cl}_{2}, 25^{\circ} \mathrm{C}$ ) of compound 11 (black, in the center), as compared to those of its precursor $2 \cdot \mathrm{BAr}^{\mathrm{F}}$ (top, red color) and an authentic sample of [(4-Bn$\left.\left.{ }^{\mathrm{iPr}} \mathrm{BIP}\right) \mathrm{Na}(\mathrm{THF})_{2}\right]\left[\mathrm{BAr}_{4}^{\mathrm{F}}\right]$ (blue, in the bottom), synthesized from 4$\mathrm{Bn}{ }^{-}{ }^{\mathrm{Pr}} \mathrm{BIP}, \mathrm{NaBAr}{ }_{4}{ }_{4}$ and THF.

$\mathrm{CH}_{2} \mathrm{Cl}_{2}$ mixture and furnished a correct elemental analysis for the formula $\left[\left({ }^{\mathrm{iPr}} \mathrm{BIP}\right) \mathrm{Na}(\mathrm{THF})\right]^{+}\left[\mathrm{BAr}_{4}^{\mathrm{F}}\right]$.

Although the recovery 11 or $\mathbf{1 2}$ from the reactions of $\mathbf{2}$ and 5 with $\mathrm{Na}\left[\mathrm{HBEt}_{3}\right]$ was not quantitative, NMR analyses of the crude reaction mixtures would not have failed to detect $\mathrm{Zn}$ complexes of type 1 or the corresponding 4-R-1,4- $\mathrm{H}_{2} \mathrm{BIP}$ dihydropyridine bases $(\mathrm{R}=$ $\mathrm{Bn}$ or $\mathrm{H}$, respectively) even if these would be formed as minor products. Cations $\mathbf{2}$ and $\mathbf{5}$ react in the same way under various experimental conditions, therefore the presence of a benzyl substituent at the pyridine $\mathrm{C} 4$ has no consequences on the regioselectivity of the nucleophilic attack. Rather, the initial attack $\left[\mathrm{HBEt}_{3}\right]^{-}$anion takes place at the metal center, and the irreversible decomposition of the resulting hydridozinc intermediate is fast enough to completely suppress the formation of dihydropyridine.

Very likely, it is the enhanced Lewis acidity of the nearly squareplanar $\mathrm{Zn}$ (II) center which dictates the initial the site of the nucleophilic attack, but the final outcome is decided by the irreversible loss of the " $\mathrm{Zn}(\mathrm{H}) \mathrm{CH}_{2} \mathrm{Ph}$ " moiety. Although the chemistry of well-defined molecular zinc hydrides has experienced a rapid development, ${ }^{51}$ compounds that contain simultaneously $\sigma-\mathrm{Zn}-\mathrm{H}$ and $\sigma-\mathrm{Zn}-\mathrm{C}$ bonds are usually unstable and just a few examples have been characterized. ${ }^{52}$ Thus, ejection of an unstable " $\mathrm{Zn}(\mathrm{H}) \mathrm{CH}_{2} \mathrm{Ph}$ " fragment provides a reasonable explanation to our results. However, we cannot rule out an alternative process, namely, unimolecular reductive elimination of toluene. In the first term, this would lead to an unstable " $\mathrm{Zn}(0)$ " species [(4-R- $\left.\left.{ }_{-}^{\mathrm{iPr}} \mathrm{BIP}\right) \mathrm{ZnL}_{\mathrm{n}}\right]$ ( $\mathrm{L}$ could be solvent or $\mathrm{N}_{2}$ ), analogous to Nikonov's $\left[\left({ }^{\mathrm{iPr}} \mathrm{BIP}\right) \mathrm{Zn}(\mathrm{DMAP})_{2}\right]$ adduct, ${ }^{9 \mathrm{a}}$ which would release the BIP ligand upon decomposition. This alternative decomposition route involving a formal reductive elimination step would open new avenues for the development of applications of zinc (and maybe other non-redox elements) in catalysis, but additional research efforts will be required to ascertain the mechanism of this interesting reaction.

\section{Conclusions and Outlook}

In this work, we investigated the ability of 2,6-bis(arylimino)pyridine ligands (BIPs) to act as hydride donor/acceptor while they are coordinated to a $\mathrm{Zn}$ (II) organometallic moiety. Our studies demonstrate that complex 1, a 1,4-dihydropyridinate $\mathrm{Zn}$ (II) complex that is cleanly formed when the ${ }^{\mathrm{iPr}} \mathrm{BIP}$ ligand reacts with dibenzylzinc contains two reactive centers, a classic $\sigma$-benzylzinc organometallic fragment and the modified dihydropyridine heterocycle. Thus, whilst the $\sigma-\mathrm{Zn}-\mathrm{C}$ bond is selectively cleaved by weak protic acids (e. g. methanol), the dearomatized dihydropyridinate ligand acts as a hydride donor, strong enough to reduce aldehydes. In contrast, the powerful Lewis-acidic electrophile $\mathrm{B}\left(\mathrm{C}_{6} \mathrm{~F}_{5}\right)_{3}$ cleanly abstracts hydride from the dihydropyridine fragment, cleanly affording the cationic organometallic $\mathrm{Zn}$ (II) species, 2, as the only detected product. This is the first time that the re-aromatization of one such alkylated species, of the type $\left[(\mathrm{R}-\mathrm{HBIP}) \mathrm{M}^{(\mathrm{II})}-\mathrm{R}\right]$, to afford the corresponding $\sigma$-alkylmetal cation $\left[(\mathrm{R}-\mathrm{BIP}) \mathrm{M}^{(\mathrm{II})}-\mathrm{R}\right]^{+}$is unambiguously demonstrated.

In order to substantiate the identity the cation 2 , we developed a general syntheses of $[(\mathrm{BIP}) \mathrm{Zn}-\mathrm{R}]^{+}$as isolable $\left[\mathrm{BAr}^{\mathrm{F}}{ }_{4}\right]^{-}$salts, based on the selective reaction of protonated BIP ligands with dialkylzinc derivatives. In contrast with previously known methods for the syntheses of BIP-supported organometallic complexes of $\mathrm{Zn}$, our methodology is straightforward and fully predictable. Next, we investigated the reaction of ionic complexes $2 \cdot \mathrm{BAr}^{\mathrm{F}}{ }_{4}$ and $\mathbf{S}$ (identical to the former but lacking the benzyl substituent at position $\mathrm{C} 4$ in the central pyridine ring) with sodium triethylhydroborate, a well-known hydride transfer reagent. Contrary to our expectations, the attack of the nucleophile takes place at the metal, causing the ejection of the 4-R${ }^{\mathrm{iPr}} \mathrm{BIP}$ ligands that were recovered as the corresponding $\mathrm{Na}^{+}$complexes. This outcome is doubtless favored by the flat coordination environment enforced by the planar BIP ligand at the $\mathrm{Zn}$ (II) center, despite the considerable steric hindrance of the aryl substituents on the ${ }^{\mathrm{iPr}} \mathrm{BIP}$ ligands. At this point of our research we are still unable to tell which the fate of the benzylzinc fragment was after the attack of the hydroborate, but there are good reasons to believe that this could be controlled with a suitable choice of substituents attached at the 
metal or the BIP ligand. Our observations suggest that more exciting discoveries are still awaiting in the exploration of the unusual and always surprising chemistry of organometallic complexes supported by BIP ligands.

\section{EXPERIMENTAL SECTION}

All manipulations were carried out under inert atmosphere using conventional Schlenk techniques $\left(\mathrm{N}_{2}\right.$ or $\mathrm{Ar}$ ) or an inert $\mathrm{N}_{2}$-filled glove box. The solvents employed (toluene, diethylether, hexane, dichlorometane, pentane and tetrahydrofurane) were rigorously dried, distilled and degassed prior use. Methanol was refluxed over sodium methoxide, distilled and stored in a glass ampoule over activated molecular sieves under inert atmosphere. NMR spectra were recorded on Bruker Avance III-400 and DRX-500 spectrometers (FT 400 and $500 \mathrm{MHz},{ }^{1} \mathrm{H} ; 100$ and $125 \mathrm{MHz},{ }^{13} \mathrm{C}$ ). The ${ }^{1} \mathrm{H}$ and ${ }^{13} \mathrm{C}\left\{{ }^{1} \mathrm{H}\right\}$ resonances of the solvent were used as the internal standard but the chemical shifts are reported with respect to TMS. The assignations were routinely helped with $2 \mathrm{D}^{1} \mathrm{H}-{ }^{1} \mathrm{H} \mathrm{COSY},{ }^{1} \mathrm{H}-{ }^{13} \mathrm{C}$ HSQC and $\mathrm{HMBC}$ heterocorrelation spectra. Dichloromethane- $\mathrm{d}_{2}$ was dried over activated $\mathrm{CaH}_{2}$ and then, vacuum-distilled. Mass spectroscopy, elemental analysis and $\mathrm{x}$-ray diffraction measurements were carried out in the Instituto de Investigaciones Químicas. $1 \mathrm{M}$ solution of $\mathrm{Na}^{+}\left[\mathrm{HBEt}_{4}\right]^{-}$in toluene, and $\mathrm{B}\left(\mathrm{C}_{6} \mathrm{~F}_{5}\right)_{3}$, were purchased from Sigma-Aldrich. The latter was purified by sublimation prior to use. The ligands 2,6-[2,6- $\left.\mathrm{Pr}_{2} \mathrm{C}_{6} \mathrm{H}_{3} \mathrm{~N}=\mathrm{C}(\mathrm{Me})\right]_{2} \mathrm{C}_{5} \mathrm{H}_{3} \mathrm{~N}$ ( ${ }^{\mathrm{iPr}} \mathrm{BIP}$ ) and 2,6$\left[2,4,6-\mathrm{Me}_{3}-\mathrm{C}_{6} \mathrm{H}_{2} \mathrm{~N}=\mathrm{C}(\mathrm{Me})\right]_{2} \mathrm{C}_{5} \mathrm{H}_{3} \mathrm{~N}$ ( ${ }^{\text {Mes }} \mathrm{BIP}$ ) were prepared condensing 2,6-diacetylpyridine with the corresponding anilines under azeotropic water-removal conditions, according to standard procedures. The tetraarylborate reagents $\left[\mathrm{H}\left(\mathrm{Et}_{2} \mathrm{O}\right)_{2}\right]^{+}\left[\mathrm{BAr}_{4}^{\mathrm{F}}\right]^{-}$and $\mathrm{Na}^{+}\left[\mathrm{BAr}_{4}^{\mathrm{F}}\right]^{-}\left(\mathrm{Ar}^{\mathrm{F}}=3,5-\right.$ $\left.\left(\mathrm{CF}_{3}\right)_{2} \mathrm{C}_{6} \mathrm{H}_{3}\right),{ }^{53}$ were prepared as described in the literature. The zinc alkyl precursors $\mathrm{ZnR}_{2}\left(\mathrm{R}=\mathrm{CH}_{2} \mathrm{SiMe}_{3}, \mathrm{CH}_{2} \mathrm{Ph}, \mathrm{CH}_{2} \mathrm{CMe}_{2} \mathrm{Ph}\right),{ }^{22}$ the alkylated BIP derivative $4-\mathrm{Bn}^{\mathrm{iPr}}{ }^{\mathrm{P}} \mathrm{BIP}^{16 a}$, the dihydropyridinate complex $\mathbf{1}^{22}$ and the protonated tetraaryborate salt $\left[\mathrm{H}^{\mathrm{iPr}} \mathrm{BIP}\right]^{+}\left[\mathrm{BAr}_{4}^{\mathrm{F}}\right]^{-16 \mathrm{~b}}$ were prepared according to our own methods, as previously described. Detailed procedures for the syntheses and full characterization data for other protonated ligands, are given in the Supporting Information.

Reaction of complex 1 with $\mathrm{B}\left(\mathrm{C}_{6} \mathrm{~F}_{5}\right)_{3}$. In situ characterization of 2.HB $\left(\mathrm{C}_{6} \mathrm{~F}_{5}\right)_{3}$. In a nitrogen filled glovebox, two solutions were prepared in equal amounts of $\mathrm{CD}_{2} \mathrm{Cl}_{2}(0.4 \mathrm{~mL})$, one containing $\mathrm{B}\left(\mathrm{C}_{6} \mathrm{~F}_{5}\right)_{3}(3.6 \mathrm{mg} ; 7 \mu \mathrm{mol})$ and the second $\left[\left(4-\mathrm{Bn}^{\left.-{ }^{\mathrm{iPr}} \mathrm{HBIP}\right)}\right.\right.$ $\mathrm{Zn}(\mathrm{Bn})]$ (1) (5.0 mg; $7 \mu \mathrm{mol})$, using $5 \mathrm{~mL}$ scintillation vials. These were cooled at $10^{\circ} \mathrm{C}$ and then the colorless solution of the borane was carefully added to the clear, deep blue solution of 1 . The resulting mixture turned red-purple instantaneously. The content of the vial was transferred into a screw-cap J. Young NMR tube at $23^{\circ} \mathrm{C}$ and analyzed by multinuclear NMR $\left({ }^{1} \mathrm{H} ;{ }^{13} \mathrm{C} ;{ }^{19} \mathrm{~F} ;{ }^{11} \mathrm{~B}\right)$. The reaction was found to be complete by the total disappearance of the signals of $\mathbf{1}$ and the clean appearance of those of $2 .{ }^{1} \mathrm{H}$ NMR: $\left(\mathrm{CD}_{2} \mathrm{Cl}_{2}, 25^{\circ} \mathrm{C}\right.$, $400 \mathrm{MHz}): \delta 1.02\left(\mathrm{~d}, 12 \mathrm{H},{ }^{3} \mathrm{HH}=6.8 \mathrm{~Hz}, \mathrm{CHMe} M e\right), 1.08(\mathrm{~d}, 12 \mathrm{H}$, $\left.{ }^{3} J_{\mathrm{HH}}=6.8 \mathrm{~Hz}, \mathrm{CHMeMe}\right), 1.79(\mathrm{~s}, 2 \mathrm{H}, \mathrm{CH} / \mathrm{Zn}-\mathrm{Bn}), 2.45(\mathrm{~s}, 6 \mathrm{H}$ $\mathrm{Me}-\mathrm{CN}), 2.45$ (sept, $\left.4 \mathrm{H},{ }^{3} \mathrm{HH}=6.8 \mathrm{~Hz}, \mathrm{C} H \mathrm{Me}_{2}\right), 4.33\left(\mathrm{~s}, 2 \mathrm{H}, \mathrm{CH}_{2}\right.$ Py-Bn), $5.53\left(\mathrm{~d}, 2 \mathrm{H},{ }^{3} J_{\mathrm{HH}}=6.6 \mathrm{~Hz}, o-\mathrm{C} H_{\mathrm{Ar}} \mathrm{Py}-\mathrm{Bn}\right), 6.55(\mathrm{~m}, 3 \mathrm{H}, m-$ $\left.\mathrm{C} H_{\mathrm{Ar}} p-\mathrm{C} H_{\mathrm{Ar}} \mathrm{Py}-\mathrm{Bn}\right), 7.29-7.44\left(\mathrm{~m}, 5 \mathrm{H}, \mathrm{C} H_{\mathrm{Ar}} \mathrm{Zn}-\mathrm{Bn}\right), 7.33$ (d, $4 \mathrm{H}$, $\left.{ }^{3} J_{\mathrm{HH}}=7.8 \mathrm{~Hz}, m-\mathrm{C} H_{\mathrm{N}-\mathrm{Ar}}\right), 7.42\left(\mathrm{t}, 2 \mathrm{H},{ }^{3} J_{\mathrm{HH}}=7.9 \mathrm{~Hz}, p-\mathrm{C} H_{\mathrm{N}-\mathrm{Ar}}\right), 8.18$ (s, $\left.2 \mathrm{H}, 3-\mathrm{C} H_{\mathrm{Py}}\right) .^{13} \mathrm{C}\left\{{ }^{1} \mathrm{H}\right\} \mathrm{NMR}\left(\mathrm{CD}_{2} \mathrm{Cl}_{2}, 25^{\circ} \mathrm{C}, 100 \mathrm{MHz}\right): \delta 18.4$ $\left(C \mathrm{H}_{2} \mathrm{Zn}-\mathrm{Bn}\right), 18.6(\mathrm{Me}-\mathrm{CN}), 22.9(\mathrm{CHMe} M e), 24.0(\mathrm{CHMeMe})$, $29.0\left(C \mathrm{HMe}_{2}\right), 41.8\left(\mathrm{CH}_{2} \mathrm{Py}-\mathrm{Bn}\right), 121.0\left(p-C \mathrm{H}_{\mathrm{Ar}} \mathrm{Zn}-\mathrm{Bn}\right), 124.6$ $\left(m-C \mathrm{H}_{\mathrm{N}-\mathrm{Ar}}\right), 126.5\left(o-C \mathrm{H}_{\mathrm{Ar}} \mathrm{Zn}-\mathrm{Bn}\right), 127.6\left(3-C \mathrm{H}_{\mathrm{P} y}\right), 127.7(m-$ $\left.C \mathrm{H}_{\mathrm{Ar}} \mathrm{Py}-\mathrm{Bn}\right), 128.0\left(p-\mathrm{CH}_{\mathrm{Ar}} \mathrm{Py}-\mathrm{Bn}\right), 128.2\left(m-\mathrm{CH}_{\mathrm{Ar}} \mathrm{Zn}-\mathrm{Bn}\right), 129.2$ (o- $\left.C \mathrm{H}_{\mathrm{Ar}} \mathrm{Py}-\mathrm{Bn}\right), 129.5$ ( $p$ - $C \mathrm{H}_{\mathrm{N}-\mathrm{Ar}}$ ), 136.1 (i-C $\left.C_{\mathrm{Ar}} \mathrm{Py}-\mathrm{Bn}\right), 137.8$ (o$\left.C_{\mathrm{N}-\mathrm{Ar}}\right), 141.5\left(i-C_{\mathrm{N}-\mathrm{Ar}}\right), 146.0\left(i-C_{\mathrm{Ar}} \mathrm{Zn}-\mathrm{Bn}\right), 148.9\left(2-C_{\mathrm{Py}}\right), 161.8(4-$ $\left.C \mathrm{Hp}_{\mathrm{y}}\right), 166.9(\mathrm{Me}-\mathrm{CN}) .{ }^{11} \mathrm{~B}\left\{{ }^{1} \mathrm{H}\right\} \mathrm{NMR}\left(128 \mathrm{MHz}, 25^{\circ} \mathrm{C}, \mathrm{CD}_{2} \mathrm{Cl}_{2}\right)$ : $\delta-27.3$ ppm. ${ }^{19} \mathrm{~F}\left\{{ }^{1} \mathrm{H}\right\}$ NMR $\left(376 \mathrm{MHz}, 25^{\circ} \mathrm{C}, \mathrm{CD}_{2} \mathrm{Cl}_{2}\right): \delta-133.8$ $\left(\mathrm{d},{ }^{3} J_{\mathrm{FF}}=19.4 \mathrm{~Hz}\right),-164.6\left(\mathrm{t},{ }^{3} \mathrm{FF}=19.4 \mathrm{~Hz}\right),-167.5\left(\mathrm{t},{ }^{3} J_{\mathrm{FF}}=20 \mathrm{~Hz}\right)$.
Synthesis of inoic complexes [(4-R-BIP) $\left.\mathrm{ZnR}^{\prime}\right]\left[\mathrm{BAr}^{\mathrm{P}}{ }_{4}\right]^{-}$These were prepared from the corresponding protonated BIP ligands and zinc dialkyls. As an example, the detailed procedure for syntheses $\mathbf{2} \cdot \mathbf{B A r}^{\mathrm{P}}{ }_{4}$ is described below, and full procedures and characterization data are given in the Supporting information. A solution of [4-Bn$\left.\mathrm{H}^{\mathrm{iPr}} \mathrm{BIP}\right]^{+}\left[\mathrm{BAr}^{\mathrm{F}}\right]^{-}(408.0 \mathrm{mg}, 0.29 \mathrm{mmol})$ in $10 \mathrm{~mL}$ of $\mathrm{CH}_{2} \mathrm{Cl}_{2}$ solution was added dropwise to a gas-tight centrifuge cone cooled to -60 ${ }^{\circ} \mathrm{C}$ containing a second solution of $\mathrm{Zn}\left(\mathrm{CH}_{2} \mathrm{Ph}\right)_{2} \quad(90.0 \mathrm{mg}, 0.36$ $\mathrm{mmol}$ ) in $10 \mathrm{~mL}$ of the same solvent and stirred with a small magnetic bar. The cooling bath was removed, and the stirring was continued for $2 \mathrm{~h}$ at the room temperature. After evaporation of volatiles, the residue was washed with hexane $(3 \times 5 \mathrm{~mL})$. After each washing, the mixture was centrifuged and the hexane decanted out with a cannula. The product was obtained as an orange microcrystalline powder that was dried under vacuum. Yield, $398 \mathrm{mg}(0.27$ mmol, $92 \%) .{ }^{1} \mathrm{H} \mathrm{NMR}\left(\mathrm{CD}_{2} \mathrm{Cl}_{2}, 25^{\circ} \mathrm{C}, 400 \mathrm{MHz}\right): \delta 1.05(\mathrm{~d}, 12 \mathrm{H}$, $\left.{ }^{3} J_{\mathrm{HH}}=7.2 \mathrm{~Hz}, \mathrm{CHMeMe}\right), 1.07\left(\mathrm{~d}, 12 \mathrm{H},{ }^{3}{ }_{\mathrm{HH}}=7.7 \mathrm{~Hz}, \mathrm{CHMeMe}\right)$, 1.69 (s, $\left.2 \mathrm{H}, \mathrm{CH}_{2} \mathrm{Zn}-\mathrm{Bn}\right), 2.44$ (s, 6H, Me-CN), $2.46\left(\mathrm{sept}, 4 \mathrm{H},{ }^{3} \mathrm{HHH}_{\mathrm{HH}}\right.$ $\left.=6.9 \mathrm{~Hz}, \mathrm{C} H \mathrm{Me}_{2}\right), 4.36\left(\mathrm{~s}, 2 \mathrm{H}, \mathrm{C} H_{2} \mathrm{Py}-\mathrm{Bn}\right), 5.60\left(\mathrm{~d}, 2 \mathrm{H},{ }^{3}{ }_{\mathrm{HH}}=6.4\right.$ $\left.\mathrm{Hz}, o-C H_{\mathrm{Ar}} \mathrm{Zn}-\mathrm{Bn}\right), 6.59\left(\mathrm{~m}, 3 \mathrm{H}, m y p-\mathrm{C} H_{\mathrm{Ar}} \mathrm{Zn}-\mathrm{Bn}\right), 7.23-7.46(\mathrm{~m}$, $\left.5 \mathrm{H}, \mathrm{C} H_{\mathrm{Ar}} \mathrm{Py}-\mathrm{Bn}\right), 7.33\left(\mathrm{~d}, 4 \mathrm{H},{ }^{3}{ }_{\mathrm{HH}}=7.5 \mathrm{~Hz}, m-\mathrm{C} H_{\mathrm{N}-\mathrm{Ar}}\right), 7.42(\mathrm{t}, 2 \mathrm{H}$, $\left.{ }^{3} J_{\mathrm{HH}}=7.5 \mathrm{~Hz}, p-\mathrm{C} H_{\mathrm{N}-\mathrm{Ar}}\right), 7.55\left(\mathrm{~s}, 4 \mathrm{H}, p-\mathrm{C} H_{\mathrm{Ar}} \mathrm{BAr}_{4}{ }_{4}\right), 7.72(\mathrm{~s}, 8 \mathrm{H}, o-$ $\left.\mathrm{C} H_{\mathrm{Ar}} \mathrm{BAr}_{4}^{\mathrm{F}}\right), 8.18\left(\mathrm{~s}, 2 \mathrm{H}, 3-\mathrm{C} H_{\mathrm{Py}}\right) .{ }^{13} \mathrm{C}\left\{{ }^{1} \mathrm{H}\right\}-\mathrm{NMR}\left(\mathrm{CD}_{2} \mathrm{Cl}_{2}, 25^{\circ} \mathrm{C}\right.$, $100 \mathrm{MHz}): \delta 18.1\left(\mathrm{CH}_{2} \mathrm{Zn}-\mathrm{Bn}\right), 18.5(\mathrm{Me}-\mathrm{CN}), 22.9(\mathrm{CHMe} M e)$, 24.1 (CHMeMe), $29.1\left(\mathrm{CHMe}_{2}\right), 42.0\left(\mathrm{CH}_{2} \mathrm{Py}-\mathrm{Bn}\right), 117.5$ (s, $p$ $\left.C \mathrm{H}_{\mathrm{Ar}} \mathrm{BAr}^{\mathrm{F}}{ }_{4}\right), 121.1\left(p-C \mathrm{H}_{\mathrm{Ar}} \mathrm{Zn}-\mathrm{Bn}\right), 124.7\left(m-C \mathrm{H}_{\mathrm{N}-\mathrm{Ar}}\right), 124.7(\mathrm{q}$, $\left.{ }^{1} J_{\mathrm{CF}}=272 \mathrm{~Hz}, C \mathrm{~F}_{3} \mathrm{BAr}_{4}{ }_{4}\right), 126.1\left(o-\mathrm{CH}_{\mathrm{Ar}} \mathrm{Zn}-\mathrm{Bn}\right), 127.7\left(m-\mathrm{CH}_{\mathrm{Ar}}\right.$ Py-Bn), $127.7\left(3-C \mathrm{H}_{\mathrm{Py}}\right), 128.1\left(p-C \mathrm{H}_{\mathrm{Ar}} \mathrm{Py}-\mathrm{Bn}\right), 128.2\left(m-C \mathrm{H}_{\mathrm{Ar}} \mathrm{Zn}\right.$ $\mathrm{Bn}), 128.9\left(\mathrm{q},{ }^{2} J_{\mathrm{CF}}=31 \mathrm{~Hz}, C-\mathrm{CF}_{3} \mathrm{BAr}^{\mathrm{F}}{ }_{4}\right), 129.0\left(o-C_{\mathrm{Ar}} \mathrm{Py}-\mathrm{Bn}\right)$, $129.6\left(p-C \mathrm{H}_{\mathrm{N}-\mathrm{Ar}}\right), 134.8\left(\mathrm{~s}, o-C \mathrm{H}_{\mathrm{Ar}} \mathrm{BAr}^{\mathrm{F}}{ }^{\mathrm{F}}\right), 136.0\left(i-C_{\mathrm{Ar}} \mathrm{Py}-\mathrm{Bn}\right)$, $137.7\left(o-C_{\mathrm{N}-\mathrm{Ar}}\right), 141.1\left(i-C_{\mathrm{N}-\mathrm{Ar}}\right), 148.9\left(2-C_{\mathrm{Py}}\right), 161.8\left(\mathrm{q},{ }^{1} J_{\mathrm{CB}}=50 \mathrm{~Hz}\right.$, $\left.i-C_{\mathrm{Ar}} \mathrm{BAr}^{\mathrm{F}}{ }^{4}\right), 162.3\left(4-C_{\mathrm{P}_{\mathrm{y}}}\right), 166.7(\mathrm{Me}-\mathrm{CN}) .{ }^{11} \mathrm{~B}\left\{{ }^{1} \mathrm{H}\right\}$ NMR $(128$ $\left.\mathrm{MHz}, 25{ }^{\circ} \mathrm{C}, \mathrm{CD}_{2} \mathrm{Cl}_{2}\right): \delta-6.60 .{ }^{19} \mathrm{~F}\left\{{ }^{1} \mathrm{H}\right\}$ NMR $\left(376 \mathrm{MHz}, 25{ }^{\circ} \mathrm{C}\right.$, $\left.\mathrm{CD}_{2} \mathrm{Cl}_{2}\right): \delta-62.8 \mathrm{IR}\left(\mathrm{Nujol}, \mathrm{cm}^{-1}\right): 1608, v(\mathrm{C}=\mathrm{N}, \mathrm{BIP}) ; 1277,1126$ and $886, v(\mathrm{~B}-\mathrm{C})$ for $\left[\mathrm{BAr}_{4}^{\mathrm{F}}{ }_{4}\right.$. Anal. Calcd for $\mathrm{C}_{79} \mathrm{H}_{68} \mathrm{BF}_{24} \mathrm{~N}_{3} \mathrm{Zn}$ : C, $59.62 ; \mathrm{H}, 4.31$; N, 2.64. Found: C, 59.63; H, 4.13; N, $2.40 \%$.

Reaction of compound 2. $\mathrm{BAr}^{\mathrm{P}}{ }_{4}$ with $\mathrm{Na}^{+}\left[\mathrm{HBEt}_{4}\right]$. Isolation of $[(4-$

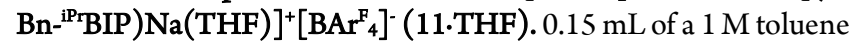
solution $\mathrm{Na}^{+}\left[\mathrm{HBEt}_{4}\right]^{-}(0.15 \mathrm{mmol})$ were added to a solution of 230 $\mathrm{mg}$ of compound $2 \cdot \mathrm{BAr}^{\mathrm{F}}{ }_{4}(0.14 \mathrm{mmol})$ in $10 \mathrm{~mL}$ of THF, stirred at $-60^{\circ} \mathrm{C}$. The color of the mixture turned instantaneously from orange to a dark bluish-green hue. The stirring was continued for 20 min and then the cooling bath was removed and the solution allowed to stir for $20 \mathrm{~min}$ at the room temperature. The color of the mixture did not fade during this time but changed slightly to olive green. It was then taken to dryness and the oily residue was stirred in hexane giving a brown solid suspended in a pale green solution. Aliquot samples of the liquid phase were taken to dryness and dissolved in $\mathrm{CD}_{2} \mathrm{Cl}_{2}$ or $\mathrm{C}_{6} \mathrm{D}_{6}$ for ${ }^{1} \mathrm{H}$ NMR analyses did not reveal the presence of any well-defined product. The solid residue was taken up in $1 \mathrm{~mL}$ $\mathrm{CH}_{2} \mathrm{Cl}_{2}$ and after adding $10 \mathrm{~mL}$ of pentane, the solution was allowed to rest at $-30{ }^{\circ} \mathrm{C}$. After $48 \mathrm{~h}$, well-shaped crystals were collected, whose $\mathrm{X}$ ray diffraction structure allowed their identification as $\mathrm{Na}^{+}\left[\mathrm{BAr}_{4}{ }_{4}^{-}\right]$. The mother liquor was filtered and taken to dryness, leaving $62 \mathrm{mg}(0.05 \mathrm{mmol})$ of an off-yellow microcrystalline residue which was identified as the compound $[\mathrm{Na}(4-\mathrm{Bn}-$ $\left.\left.{ }^{\mathrm{iPr}} \mathrm{BIP}\right)(\mathrm{THF})\right]^{+}\left[\mathrm{BAr}_{4}^{\mathrm{F}}\right]^{-}$(11.THF). Yield: 35\%. ${ }^{1} \mathrm{H} \mathrm{NMR}\left(\mathrm{CD}_{2} \mathrm{Cl}_{2}\right.$, 
$25^{\circ} \mathrm{C}, 400 \mathrm{MHz}$ ): $\delta 1.05\left(\mathrm{~d}, 12 \mathrm{H},{ }^{3} J_{\mathrm{HH}}=6.8 \mathrm{~Hz}, \mathrm{CHMe} M e\right), 1.15$ (d, $\left.12 \mathrm{H},{ }^{3} \mathrm{JHH}_{\mathrm{HH}}=6.8 \mathrm{~Hz}, \mathrm{CH} M e \mathrm{Me}\right), 1.66(\mathrm{~m}, 4 \mathrm{H}, \mathrm{THF}), 2.29(\mathrm{~s}, 6 \mathrm{H}$, Me-CN), 2.59 (sept, 4H, $\left.{ }^{3} J_{\mathrm{HH}}=6.8 \mathrm{~Hz}, \mathrm{CHMe}\right), 3.23(\mathrm{~m}, 4 \mathrm{H}$, THF), 4.27 (s, 2H, C $H_{2} \mathrm{Py}-\mathrm{Bn}$ ), $7.15-7.25$ (m, 6H, m,p-C $H_{\mathrm{N}-\mathrm{Ar}}$ ), $7.32\left(\mathrm{~d}, 2 \mathrm{H}^{3} J_{\mathrm{HH}}=7.7 \mathrm{~Hz}, o-\mathrm{CH}_{\mathrm{Ar}} \mathrm{Py}-\mathrm{Bn}\right), 7.33\left(\mathrm{t}, 1 \mathrm{H}^{3} J_{\mathrm{HH}}=7.4 \mathrm{~Hz}\right.$, $p$-C $\left.H_{\mathrm{Ar}} \mathrm{Py}-\mathrm{Bn}\right), 7.39\left(\mathrm{t}, 2 \mathrm{H}^{3} J_{\mathrm{HH}}=7.3 \mathrm{~Hz}, m-\mathrm{C} H_{\mathrm{Ar}} \mathrm{Py}-\mathrm{Bn}\right), 7.65(\mathrm{~s}$, $\left.4 \mathrm{H}, p-\mathrm{CH}_{\mathrm{Ar}} \mathrm{BAr}{ }_{4}^{\mathrm{F}}\right), 7.74\left(\mathrm{~s}, 8 \mathrm{H}, o-\mathrm{CH}_{\mathrm{Ar}} \mathrm{BAr}_{4}{ }_{4}\right), 7.96\left(\mathrm{~s}, 2 \mathrm{H}, 3-\mathrm{CH}_{\mathrm{Py}}\right)$. ${ }^{13} \mathrm{C}\left\{{ }^{1} \mathrm{H}\right\}$ NMR $\left(\mathrm{CD}_{2} \mathrm{Cl}_{2}, 25{ }^{\circ} \mathrm{C}, 100 \mathrm{MHz}\right): \delta 18.8(\mathrm{Me}-\mathrm{CN}), 23.3$ (CHMe Me), 23.6 (CHMeMe), 25.6 (THF), 28.8 ( $\mathrm{CHMe}_{2}$ ), 42.0 $\left(C \mathrm{H}_{2} \mathrm{Py}-\mathrm{Bn}\right), 68.4$ (THF), $117.8\left(\mathrm{~s}, p-C \mathrm{H}_{\mathrm{Ar}} \mathrm{BAr}^{\mathrm{F}}{ }_{4}\right), 124.4\left(m-\mathrm{CH}_{\mathrm{N}}\right.$ Ar), $125.0\left(\mathrm{q},{ }^{1} J_{\mathrm{CF}}=272 \mathrm{~Hz}, C_{\mathrm{F}_{3}} \mathrm{BAr}^{\mathrm{F}}\right), 126.2\left(3-C_{\mathrm{Py}}\right), 127.7(p-$ $\left.C \mathrm{H}_{\mathrm{N}-\mathrm{Ar}}\right), 128.5\left(p-C \mathrm{H}_{\mathrm{Ar}} \mathrm{Py}-\mathrm{Bn}\right), 129.2\left(\mathrm{q},{ }^{2} J_{\mathrm{CF}}=31 \mathrm{~Hz}, C-\mathrm{CF}_{3}\right.$ $\left.\mathrm{BAr}_{4}{ }^{\mathrm{C}}\right), 129.3\left(o-C_{\mathrm{Ar}} \mathrm{Py}-\mathrm{Bn}\right), 129.5\left(m-C_{\mathrm{Ar}} \mathrm{Py}-\mathrm{Bn}\right), 135.2(\mathrm{~s}, o-$ $\left.C_{\mathrm{Ar}} \mathrm{BAr}^{\mathrm{F}}{ }_{4}\right), 136.4\left(o-C_{\mathrm{N}-\mathrm{Ar}}\right), 138.0\left(i-C_{\mathrm{Ar}} \mathrm{Py}-\mathrm{Bn}\right), 144.3\left(i-C_{\mathrm{N}-\mathrm{Ar}}\right)$, $153.2\left(2-C_{\mathrm{Py}}\right), 156.9\left(4-C_{\mathrm{Py}}\right), 162.1\left(\mathrm{q},{ }^{1} J_{\mathrm{CB}}=50 \mathrm{~Hz}, i-C_{\mathrm{Ar}} \mathrm{BAr}_{4}^{\mathrm{F}}\right)$, 169.1 (Me-CN). ${ }^{11} \mathrm{~B}\left\{{ }^{1} \mathrm{H}\right\} \mathrm{NMR}\left(128 \mathrm{MHz}, 25{ }^{\circ} \mathrm{C}, \mathrm{CD}_{2} \mathrm{Cl}_{2}\right): \delta-$ 6.60. ${ }^{19} \mathrm{~F}\left\{{ }^{1} \mathrm{H}\right\}$ NMR $\left(376 \mathrm{MHz}, 25^{\circ} \mathrm{C}, \mathrm{CD}_{2} \mathrm{Cl}_{2}\right): \delta$-62.8. ESI-MS $\left(\mathrm{CH}_{2} \mathrm{Cl}_{2}\right): 594.5\left(4-\mathrm{Bn}^{-}{ }^{\mathrm{iPr}} \mathrm{BIPNa}^{+}\right)$.

Reaction of compound 5 with $\mathrm{Na}^{+}\left[\mathrm{HBEt}_{3}\right]$. Isolation of $\left[\left({ }^{\mathrm{iP}} \mathrm{BIP}\right) \mathrm{Na}\right]^{+}\left[\mathrm{BAr}_{4}\right]^{-}$(12). A $0.064 \mathrm{M}$ toluene solution of $\mathrm{Na}^{+}\left[\mathrm{HBEt}_{3}\right]^{-}$was prepared diluting the $1 \mathrm{M}$ commercial solution in the required volume of the same solvent. $1 \mathrm{~mL}$ of this solution $(0.064$ $\mathrm{mmol})$ was added to a suspension of compound $5(91.6 \mathrm{mg}, 0.064$ $\mathrm{mmol}$ ) in $5 \mathrm{~mL}$ of toluene, vigorously stirred at the room temperature. The orange suspension turned pale yellow. The stirring was continued for $3 \mathrm{~h}$ followed by evaporation under reduced pressure. The residue was washed with hexane $(3 \times 10 \mathrm{~mL})$ and after filtration, and it was dried under vacuum. The hexane extracts were analyzed by ${ }^{1} \mathrm{H}$ NMR evidencing that these did not contain any substantial amount of well-defined products species, whereas the ${ }^{1} \mathrm{H}$ spectrum of the solid in $\mathrm{CD}_{2} \mathrm{Cl}_{2}$ revealed that it consisted of spectroscopically pure $\left[\left({ }^{\mathrm{iPr}} \mathrm{BIP}\right) \mathrm{Na}\right]^{+}\left[\mathrm{BAr}_{4}^{\mathrm{F}}\right]^{-}$(12). ${ }^{1} \mathrm{H} \mathrm{NMR}\left(\mathrm{CD}_{2} \mathrm{Cl}_{2}, 25^{\circ} \mathrm{C}, 400\right.$ $\mathrm{MHz}): \delta 1.10\left(\mathrm{~d}, 12 \mathrm{H},{ }^{3} \mathrm{HH}_{\mathrm{HH}}=6.6 \mathrm{~Hz}, \mathrm{CHMe} M e\right), 1.15\left(\mathrm{~d}, 12 \mathrm{H},{ }^{3} \mathrm{JH}_{\mathrm{HH}}\right.$ $=6.6 \mathrm{~Hz}, \mathrm{CHMeMe}), 2.33(\mathrm{~s}, 6 \mathrm{H}, M e-\mathrm{CN}), 2.59\left(\mathrm{sept}, 4 \mathrm{H},{ }^{3} J_{\mathrm{HH}}=\right.$ $\left.6.7 \mathrm{~Hz}, \mathrm{C} H \mathrm{Me}_{2}\right), 7.24\left(\mathrm{~m}, 6 \mathrm{H}, m\right.$ y $\left.p-\mathrm{CH}_{\mathrm{N}-\mathrm{Ar}}\right), 7.55\left(\mathrm{~s}, 4 \mathrm{H}, p-\mathrm{CH}_{\mathrm{Ar}}\right.$ $\left.\mathrm{BAr}_{4}{ }^{\mathrm{F}}\right), 7.73\left(\mathrm{~s}, 8 \mathrm{H}, o-\mathrm{CH}_{\mathrm{Ar}} \mathrm{BAr}_{4}^{\mathrm{F}}\right), 8.11\left(\mathrm{~d}, 2 \mathrm{H},{ }^{3} \mathrm{HH}_{\mathrm{HH}}=7.8 \mathrm{~Hz}, 3-\right.$ $\left.\mathrm{C} H_{\mathrm{Py}}\right), 8.25\left(\mathrm{t}, 1 \mathrm{H},{ }^{3} J_{\mathrm{HH}}=7.8 \mathrm{~Hz}, 4-\mathrm{CH}_{\mathrm{Py}}\right)$. ESI-MS (THF): 504.5 $\left({ }^{\mathrm{iPr}} \mathrm{BIPNa}^{+}\right)$.

Independent synthesis of $\left[\mathrm{Na}\left(4-\mathrm{Bn}{ }^{-\mathrm{PP}} \mathrm{BIP}\right)(\mathrm{THF})_{2}\right]^{+}\left[\mathrm{BAr}_{4}^{\mathrm{F}}\right]$ (11.(THF) $\left.)_{2}\right) .0 .334 \mathrm{~g}$ of $\mathrm{Na}\left[\mathrm{BAr}_{4}^{\mathrm{F}}\right](0.38 \mathrm{mmol})$ were dissolved in a mixture of solvents containing $8 \mathrm{~mL}$ of $\mathrm{CH}_{2} \mathrm{Cl}_{2}$ and $0.5 \mathrm{~mL}$ of THF. Then, while stirring, an equimolar amount of $4-\mathrm{Bn}-{ }^{\mathrm{iPr}} \mathrm{BIP}(0.216 \mathrm{~g}$, $0.38 \mathrm{mmol}$ ) in $8 \mathrm{~mL}$ of $\mathrm{CH}_{2} \mathrm{Cl}_{2}$ were added. The mixture was stirred for $60 \mathrm{~min}$. Then, volatiles and solvents were removed under reduced pressure and the resultant yellow solid was washed with pentane $(10 \mathrm{~mL})$ and dried under vacuum during 2 hours. Yield: $222 \mathrm{mg}$, $0.23 \mathrm{mmol}(61 \%)$. Attempts to crystallize this compound were unsuccessful due to its high solubility. On prolonged storage at $-20^{\circ} \mathrm{C}$, partial precipitation of $\mathrm{Na}\left[\mathrm{BAr}^{\mathrm{F}}{ }_{4}\right]$ took place. ${ }^{1} \mathrm{H} \mathrm{NMR}\left(\mathrm{CH}_{2} \mathrm{Cl}_{2}, 25\right.$ $\left.{ }^{\circ} \mathrm{C}, 400 \mathrm{MHz}\right): \delta 1.04\left(\mathrm{~d}, 12 \mathrm{H},{ }^{3} J_{\mathrm{HH}}=6.8 \mathrm{~Hz}, \mathrm{CHMeMe}\right), 1.14(\mathrm{~d}$, $\left.12 \mathrm{H},{ }^{3} J_{\mathrm{HH}}=6.8 \mathrm{~Hz}, \mathrm{CHMeMe}\right), 1.71(\mathrm{~m}, 8 \mathrm{H}, \mathrm{THF}), 2.29(\mathrm{~s}, 6 \mathrm{H}$, $\mathrm{Me}-\mathrm{CN}), 2.57\left(\mathrm{sept}, 4 \mathrm{H},{ }^{3} \mathrm{JHH}_{\mathrm{HH}}=6.9 \mathrm{~Hz}, \mathrm{CHMe}_{2}\right), 3.39(\mathrm{~m}, 8 \mathrm{H}$, THF), 4.25 (s, 2H, C $H_{2} \mathrm{Py}-\mathrm{Bn}$ ), 7.17 - 7.23 (m, 6H, m,p-C $H_{\mathrm{N}-\mathrm{Ar}}$ ), $7.31\left(\mathrm{~d}, 2 \mathrm{H}^{3} J_{\mathrm{HH}}=7.7 \mathrm{~Hz}, o-\mathrm{CH}_{\mathrm{Ar}} \mathrm{Py}-\mathrm{Bn}\right), 7.33\left(\mathrm{t}, 1 \mathrm{H}^{3} J_{\mathrm{HH}}=7.7 \mathrm{~Hz}\right.$, $p$-C $\left.H_{\mathrm{Ar}} \mathrm{Py}-\mathrm{Bn}\right), 7.39\left(\mathrm{t}, 2 \mathrm{H}^{3} \mathrm{JHH}_{\mathrm{HH}}=7.3 \mathrm{~Hz}, m-\mathrm{C} H_{\mathrm{Ar}} \mathrm{Py}-\mathrm{Bn}\right), 7.55$ (s, $\left.4 \mathrm{H}, p-\mathrm{CH}_{\mathrm{A} r} \mathrm{BAr}^{\mathrm{F}}{ }_{4}\right), 7.72\left(\mathrm{~s}, 8 \mathrm{H}, o-\mathrm{CH}_{\mathrm{Ar}} \mathrm{BAr}^{\mathrm{F}}{ }_{4}\right), 7.94(\mathrm{~s}, 2 \mathrm{H}, 3-$ $\left.\mathrm{C} H_{\mathrm{Py}}\right) .{ }^{13} \mathrm{C}\left\{{ }^{1} \mathrm{H}\right\} \mathrm{NMR}\left(\mathrm{CD}_{2} \mathrm{Cl}_{2}, 25^{\circ} \mathrm{C}, 100 \mathrm{MHz}\right): \delta 18.8(\mathrm{Me}-\mathrm{CN})$, 23.3 (CHMe Me), 23.7 (CHMeMe), 25.8 (THF), 28.8( $\left.C \mathrm{HMe}_{2}\right)$,
42.1 ( $\left.\mathrm{CH}_{2} \mathrm{Py}-\mathrm{Bn}\right), 68.3$ (THF), 117.8 (s, $\left.p-\mathrm{CH}_{\mathrm{Ar}} \mathrm{BAr}_{4}^{\mathrm{F}}\right), 124.4(m-$ $\left.C \mathrm{H}_{\mathrm{N}-\mathrm{Ar}}\right), 125.2\left(\mathrm{q},{ }^{1} J_{\mathrm{CF}}=272 \mathrm{~Hz}, C \mathrm{~F}_{3} \mathrm{BAr}^{\mathrm{F}}{ }_{4}\right), 126.2\left(3-C_{\mathrm{Py}}\right), 126.4$ $\left(p-C \mathrm{H}_{\mathrm{N}-\mathrm{Ar}}\right), 127.8\left(p-C_{\mathrm{Ar}} \mathrm{Py}-\mathrm{Bn}\right), 129.2\left(\mathrm{q},{ }^{2} J_{\mathrm{CF}}=31 \mathrm{~Hz}, C-\mathrm{CF}_{3}\right.$ $\mathrm{BAr}^{\mathrm{F}}$ ), $129.3\left(o-C \mathrm{H}_{\mathrm{Ar}} \mathrm{Py}-\mathrm{Bn}\right), 129.6\left(m-C_{\mathrm{Ar}} \mathrm{Py}-\mathrm{Bn}\right), 135.2(\mathrm{~s}, o-$ $\left.C_{\mathrm{Ar}} \mathrm{BAr}^{\mathrm{F}}{ }_{4}\right), 136.5\left(o-C_{\mathrm{N}-\mathrm{Ar}}\right), 138.1\left(i-C_{\mathrm{Ar}} \mathrm{Py}-\mathrm{Bn}\right), 144.4\left(i-C_{\mathrm{N}-\mathrm{Ar}}\right)$, $153.3\left(2-C_{\mathrm{Py}}\right), 156.8\left(4-C_{\mathrm{Py}}\right), 162.1\left(\mathrm{q},{ }^{1} J_{\mathrm{CB}}=50 \mathrm{~Hz}, i-C_{\mathrm{Ar}} \mathrm{BAr}_{4}^{\mathrm{F}}\right)$, $169.1(\mathrm{Me}-\mathrm{CN})$.ESI-MS $\left(\mathrm{CH}_{2} \mathrm{Cl}_{2}\right): 594.5\left(4-\mathrm{Bn}^{-}{ }^{\mathrm{iPr}} \mathrm{BIPNa}^{+}\right)$. Anal. Calcd for $\mathrm{C}_{80} \mathrm{H}_{49} \mathrm{BF}_{24} \mathrm{~N}_{3} \mathrm{NaO}_{2} \cdot 2 \mathrm{CH}_{2} \mathrm{Cl}_{2}$ : C, 55.58; H, 4.61; N, 2.37. Found: C, 55.28; H, 4.49; N, $2.33 \%$.

Independent synthesis of $\left.\left[\left({ }^{\mathrm{PP}} \mathrm{BIP}\right) \mathrm{Na}(\mathrm{THF})\right]^{+}\left[\mathrm{BAr}^{\mathrm{P}}\right]_{4}\right]^{-}(12 \cdot \mathrm{THF})$. $241 \mathrm{mg}(0.5 \mathrm{mmol})$ of ${ }^{\mathrm{iPr}} \mathrm{BIP}$, dissolved in $8 \mathrm{~mL}$ of $\mathrm{CH}_{2} \mathrm{Cl}_{2}$, were added to a stirred solution containing $443 \mathrm{mg}(0.5 \mathrm{mmol})$ of $\mathrm{Na}\left[\mathrm{BAr}_{4}{ }_{4}\right]$ in $11 \mathrm{~mL}$ of a mixture of $\mathrm{CH}_{2} \mathrm{Cl}_{2}$ and THF 10:1 (v/v). The reaction mixture was stirred for $1 \mathrm{~h}$, taken to dryness and the solid residue was recrystallized in a 1:4 mixture of $\mathrm{CH}_{2} \mathrm{Cl}_{2}$ and hexane at $-20{ }^{\circ} \mathrm{C}$. A pale yellow microcrystalline solid formed after $48 \mathrm{~h}$, which was filtered out, and dried under reduced pressure $(552 \mathrm{mg}$; $0.383 \mathrm{mmol}, 77 \%$ yield). ${ }^{1} \mathrm{H} \mathrm{NMR}\left(\mathrm{CD}_{2} \mathrm{Cl}_{2}, 25{ }^{\circ} \mathrm{C}, 400 \mathrm{MHz}\right)$ : $\delta 1.11\left(\mathrm{~d}, 12 \mathrm{H},{ }^{3} J_{\mathrm{HH}}=6.8 \mathrm{~Hz}, \mathrm{CHMeMe}\right), 1.19\left(\mathrm{~d}, 12 \mathrm{H},{ }^{3} J_{\mathrm{HH}}=6.9\right.$ $\mathrm{Hz}, \mathrm{CHMeMe}$ ), 1.69 (m, 4H, THF), 2.37 (s, 6H, Me-CN), 2.65 (sept, $4 \mathrm{H}^{3} \mathrm{JHH}_{\mathrm{HH}}=6.8 \mathrm{~Hz}, \mathrm{CHMe}$ ), $3.28(\mathrm{~m}, 4 \mathrm{H}, \mathrm{THF}), 7.29-7.24(\mathrm{~m}$, $\left.6 \mathrm{H}, m, p-\mathrm{C} H_{\mathrm{N}-\mathrm{Ar}}\right), 7.60\left(\mathrm{~s}, 4 \mathrm{H}, p-\mathrm{CH}_{\mathrm{ar}}, \mathrm{BAr}^{\mathrm{F}}{ }_{4}\right), 7.77\left(\mathrm{~s}, 8 \mathrm{H}, o-\mathrm{C} H_{\mathrm{ar}}\right.$, $\left.\mathrm{BAr}^{\mathrm{F}}{ }_{4}\right), 8.14\left(\mathrm{~d}, 2 \mathrm{H},{ }^{3} J_{\mathrm{HH}}=7.8 \mathrm{~Hz}, 3-\mathrm{CH}_{\mathrm{Py}}\right), 8.25\left(\mathrm{t}, 1 \mathrm{H},{ }^{3} J_{\mathrm{HH}}=7.9\right.$ $\left.\mathrm{Hz}, 4-\mathrm{C} H_{\mathrm{Py}}\right) .{ }^{13} \mathrm{C}\left\{{ }^{1} \mathrm{H}\right\} \mathrm{NMR}\left(\mathrm{CD}_{2} \mathrm{Cl}_{2}, 25{ }^{\circ} \mathrm{C}, 100 \mathrm{MHz}\right): \delta 18.8$ ( $\mathrm{Me}$-CN), 23.4 (CHMe $\mathrm{Me}$ ), 23.7 (CHMeMe), 25.7 (THF), 28.8 $\left(C \mathrm{HMe}_{2}\right), 68.3$ (THF), $117.9\left(\mathrm{~s}, p-\mathrm{CH}_{\mathrm{Ar}} \mathrm{BAr}^{\mathrm{F}}{ }_{4}\right), 124.7\left(m-C_{\mathrm{N}-\mathrm{Ar}}\right)$, $125.1\left(\mathrm{q},{ }^{1} J_{\mathrm{CF}}=272 \mathrm{~Hz}, C \mathrm{~F}_{3} \mathrm{BAr}^{\mathrm{F}}\right), 126.0\left(3-C \mathrm{H}_{\mathrm{Py}}\right), 126.3\left(p-C \mathrm{H}_{\mathrm{N}}\right.$ $\left.\left.{ }_{A r}\right), 129.3\left(\mathrm{q},{ }^{2} J_{\mathrm{CF}}=31 \mathrm{~Hz}, C-\mathrm{CF}_{3} \mathrm{BAr}_{4}^{\mathrm{F}}\right), 135.2\left(\mathrm{~s}, o-C \mathrm{H}_{\mathrm{Ar}} \mathrm{BAr}_{4}\right)^{\mathrm{F}}\right)$, $136.5\left(o-C_{\mathrm{N}-\mathrm{Ar}}\right), 141.3\left(4-C_{\mathrm{P}_{\mathrm{y}}}\right), 144.5\left(i-C_{\mathrm{N}-\mathrm{Ar}}\right), 153.3\left(2-C_{\mathrm{Py}}\right)$, $162.1\left(\mathrm{q},{ }^{1} J_{\text {Св }}=50 \mathrm{~Hz}, i-C_{\mathrm{Ar}} \mathrm{BAr}_{4}^{\mathrm{F}}\right), 169.0(\mathrm{Me}-C \mathrm{~N})$. ESI-MS $\left(\mathrm{CH}_{2} \mathrm{Cl}_{2}\right): 504.4\left({ }^{\mathrm{iPr}} \mathrm{BIPNa}{ }^{+}\right)$. Anal. Calcd for $\mathrm{C}_{69} \mathrm{H}_{53} \mathrm{BF}_{24} \mathrm{~N}_{3} \mathrm{NaO}: \mathrm{C}$, $57.55 ; \mathrm{H}, 4.41$; N, 2.92. Found: C, 57.23; H, 4.67; N, $2.77 \%$.

X-ray Structural Analysis for 6 and 10: Crystals suitable for X-ray diffraction analysis were coated with dry perfluoropolyether, mounted on glass fibers, and fixed in a cold nitrogen stream to the goniometer head. Data collections were performed on a Bruker-Nonius X8 Apex-II CCD diffractometer, using graphite monochromatized Mo radiation $(\lambda($ Mo $\mathrm{K} \alpha)=0.71073 \AA)$ and fine-sliced $\omega$ and $\varphi$ scans (scan widths $0.30^{\circ}$ to $\left.0.50^{\circ}\right) .^{54}$ The data were reduced (SAINT) and corrected for absorption effects by the multiscan method $(S A D A B S) .{ }^{55}$ The structures were solved by direct methods (SIR2002, SHELXS) and refined against all $F^{2}$ data by full-matrix least-squares techniques (SHELXL-2016/6) minimizing $w\left[F_{0}^{2}\right.$ $\left.F_{c}^{2}\right]^{2} .{ }^{56}$ All non-hydrogen atoms were refined with anisotropic displacement parameters. Hydrogen atoms were included in calculated positions and allowed to ride on their carrier atoms with the isotropic temperature factors $U_{\text {iso }}$ fixed at 1.2 times ( 1.5 times for methyl groups) of the $U_{\text {eq }}$ values of the respective carrier atoms. Three$\mathrm{CF}_{3}$ groups appear strongly disordered in the $\left[\mathrm{BAr}_{4}\right]^{-}$anions in both complex salts and these groups were all modeled over two sets of sites. The occupancies ratios were fixed at (50:50, 60:40 and 50:50) and (66:34, 68:32 and 56:44) respectively for 6 and 10. Moreover, two iPr-aryl groups appear disordered for 6 , which were modeled over two sets of sites with occupancies ratios fixed at 60:40 for both. This required some geometric restraints (DFIX instruction), the ADP restraint SIMU and the rigid bond restraint DELU were used in order to obtain more reasonable geometric and $\mathrm{ADP}$ values of the solvent molecule atoms. It was also useful to restraint the anisotropic 
$\mathrm{U}$-values of these atoms to behave more isotropically (ISOR instruction). A search for solvent accessible voids in 10 using PLATON, ${ }^{57}$ showed a potential solvent volume of $432 \mathrm{~A}^{3}$ and 139 count electrons (equating to 4 molecules of $n$-hexane per unit cell), impossible to model even with the most severe restraints. The corresponding CIF data represent $S Q U E E Z E^{88}$ treated structures with the n-hexane molecules handling as a diffuse contribution to the overall scattering, without specific atom position and excluded from the structural model. The SQUEEZE results were appended to the CIF.

Crystal data for 6: $\mathrm{C}_{69} \mathrm{H}_{66} \mathrm{BF}_{24} \mathrm{~N}_{3} \mathrm{SiZn}\left[\mathrm{C}_{32} \mathrm{H}_{12} \mathrm{BF}_{24}, \mathrm{C}_{37} \mathrm{H}_{54} \mathrm{~N}_{3} \mathrm{SiZn}\right]$, $M_{\mathrm{r}}=1497.51$, triclinic, space group $P \overline{1}, a=12.448(15) \AA, b=$ 16.396(18) $\AA, c=17.828(17) \AA, \alpha=94.25(4)^{\circ}, \beta=99.75(4)^{\circ}, \gamma=$ 96.70(4) $)^{\circ} V=3545(7) \AA^{3}, T=173(2) \mathrm{K}, Z=2, \mu=0.469 \mathrm{~mm}^{-1}$, 70431 reflections measured $\left(\theta_{\max }=25.25^{\circ}\right), 12740$ independent reflections $\left(R_{\mathrm{int}}=0.0403\right)$. The final R1 value was $0.0532(I>2 \sigma(I))$. The final $w \mathrm{R} 2\left(F^{2}\right)$ value was 0.1621 (all data). The goodness of fit on $F^{2}$ was 1.006. CCDC 1566705.

Crystal data for 10: $\mathrm{C}_{69} \mathrm{H}_{56} \mathrm{BF}_{24} \mathrm{~N}_{3} \mathrm{Zn}\left[\mathrm{C}_{32} \mathrm{H}_{12} \mathrm{BF}_{24}, \mathrm{C}_{37} \mathrm{H}_{44} \mathrm{~N}_{3} \mathrm{Zn}\right], M_{\mathrm{r}}$ $=1459.34$, triclinic, space group $P \overline{1}, a=12.3635(16) \AA, b=$ 14.7704(19) $\AA, c=20.859(2) \AA, \alpha=78.781(4)^{\circ}, \beta=84.371(4)^{\circ}, \gamma$ $=89.994(4)^{\circ}, V=3717.7(8) \AA^{3}, T=193(2) \mathrm{K}, Z=2, \mu=0.430 \mathrm{~mm}^{-}$ ${ }^{1}, 67960$ reflections measured $\left(\theta_{\max }=25.25^{\circ}\right), 13409$ independent reflections $\left(R_{\text {int }}=0.0822\right)$. The final $R 1$ value was $0.0951(I>2 \sigma(I))$. The final $w \mathrm{R} 2\left(F^{2}\right)$ value was 0.3223 (all data). The goodness of fit on $F^{2}$ was 1.126. CCDC 1566704 .

\section{ASSOCIATED CONTENT}

\section{Supporting Information}

The Supporting Information is available free of charge on the ACS Publications website at DOI:

Syntheses details and characterization data for protonated ligands and compounds 3-10 (PDF).

Crystallographic information for $\left[\left({ }^{\mathrm{iPr}} \mathrm{BIP}\right) \mathrm{Zn}\left(\mathrm{CH}_{2} \mathrm{SiMe}_{3}\right)\right]+\left[\mathrm{BAr}_{4}{ }_{4}\right]$

(6) and $\left[\left({ }^{\mathrm{Mes}} \mathrm{BIP}\right) \mathrm{Zn}\left(\mathrm{CH}_{2} \mathrm{CMe}_{2} \mathrm{Ph}\right)\right]^{+}\left[\mathrm{BAr}_{4}^{\mathrm{F}}\right]^{-}(\mathbf{1 0})(\mathrm{CIF})$

\section{AUTHOR INFORMATION}

\section{Corresponding Author}

*antonior@iiq.cisc.es

*campora@iiq.csic.es

The authors declare no competing financial interest

\section{ACKNOWLEDGMENT}

The Spanish Ministry of Economy and Innovation (MINECO) and the FEDER funds of the European Union (CTQ2015-68978-P) supported this work. J.J.S. gratefully thanks MICINN for a PFPI postgraduate studentship.

This work is dedicated to Prof. Ernesto Carmona, in the occasion of his $70^{\text {th }}$ birthday. We celebrate his outstanding contribution to the development of Organometallic Chemistry in Spain, and acknowledge his leadership, dedication and constant support for many years.

\section{REFERENCES AND NOTES}

(1) (a) Flisak, Z.; Sun, W. H., Progression of Diiminopyridines: From Single Application to Catalytic Versatility. ACS Catal. 2015, 5, 4173 - 4724. (b) Small, B. L., Discovery and Development of Pyridine-bis(imine) and Related Catalysts for Olefin Polymerization and Oligomerization. Acc. Chem. Res. 2015, 48, 2599 - 2611.

(2) (a) Small, B. L.; Brookhart, M.; Bennett, A. M. A., Highly Active Iron and Cobalt Catalysts for the Polymerization of Ethylene. J. Am. Chem. Soc. 1998, 120, 4049-4050. (b) Britovsek, G. J. P.; Gibson, V. C.; McTavish, S. J.; Solan, G. A.; White, A. J. P.; Williams, D. J.; Kimberley, B. S.; Maddox, P. J., Novel olefin polymerization catalysts based on iron and cobalt. Chem. Commun. 1998, 849-850.

(3) (a) Cámpora, J.; Rodríguez-Delgado, A.; Palma, P., $\sigma$-Organometallic Chemistry With 2,6-Bis(imito)pyridine Ligands: New Pathways to Innovative Pincer Architectures. In Pincer Compounds: Chemistry and Applications. Morales-Morales, D., Ed. Elsevier: Amsterdam, 2018, 26, 539-585. (b) Gibson, V. C.; Redshaw, C.; Solan, G. A., Bis(imino)pyridines: Surprisingly Reactive Ligands and a Gateway to New Families of Catalysts. Chem. Rev. 2007, 107, 1745-1776. (c) Knijnenburg, Q.; Gambarotta, S.; Budzelaar, P. H. M., Ligand-centred reactivity in diiminepyridine complexes. Dalton Trans. 2006, 5442 - 5448.

(4) Luca, O. R.; Crabtree, R. H., Redox-active ligands in catalysis. Chem. Soc. Rev. 2013, 42, 1440 - 1459.

(5) (a) Trovitch, J. R..; Lobkovsky, E.; Chirik, P., J. Bis(imino)pyridine Iron Alkyls Containing $\beta$-Hydrogens: Synthesis, Evaluation of Kinetic Stability, and Decomposition Pathways Involving Chelate Participation. J. Am. Chem. Soc. 2008, 130, 11631 - 11640. (b) Trovitch, R. J.; Lobkovsky, E.; Bowkamp, M. W.; Chirik, P. J. Carbon-Oxygen Bond Cleavage by Bis(imino)pyridine Iron Compounds: Catalyst Deactivation Pathways and Observation of Acyl C-O Bond Cleavage in Esters. Organometallics, 2008, 27, 6264 - 6278. (c) Darmon, J. M.; Stieber, S. C. E.; Sylvester, K. T.; Fernández, I.; Lobkovsky, E.; Semproni, S. P.; Bill, E.; Wieghardt, K.; DeBeer, S.; Chirik, P. J., Oxidative Addition of Carbon-Carbon Bonds with a RedoxActive Bis(imino)pyridine Iron Complex. J. Am. Chem. Soc. 2012, 134, 17125-17137. (d) Hoyt, J. M.; Sylvester, K. T.; Semproni, S. P.; Chirik, P. J., Synthesis and Electronic Structure of Bis(imino)pyridine Iron Metallacyclic Intermediates in Iron-Catalyzed Cyclization Reactions. J. Am. Chem. Soc. 2013, 138, 4862-4877.

(6) (a) Stieber, S. C. E.; Milsmann, C.; Hoyt, J. M.; Turner, Z.; Finkelstein, K. D.; Wieghardt, K.; DeBeer, S.; Chirik, P. J., Bis(imino)pyridine Iron Dinitrogen Compounds Revisited: Differences in Electronic Structure Between Four- and Five-Coordinate Derivatives. Inorg. Chem. 2012, 51, 3770 - 3785. (b) Bowman, A. C.; Milsmann, C.; Hojilla Atienza, C. C.; Lobkovsky, E.; Wieghardt, K.; Chirik, P. J., Synthesis and Molecular and Electronic Structures of Reduced Bis(imino)pyridine Cobalt Dinitrogen Complexes: Ligand versus Metal Reduction, J. Am. Chem. Soc. 2010, 132, 1676 - 1684.

(7) (a) Chirik, P. J., Iron- and Cobalt-Catalyzed Alkene Hydrogenation: Catalysis with Both Redox-Active and Strong Field Ligands. Acc. Chem. Res. 2015, 48, 1687 - 1695. (b) Sylvester, K. T.; Chirik, P. J., Iron-Catalyzed, Hydrogen-Mediated Reductive Cyclization of 1,6-Enynes and Diynes: Evidence for Bis(imino)pyridine Ligand ParticipationJ. Am. Chem. Soc. 2009, 131, 8772 - 8774.

(8) (a) Chirik, P. J.; Wieghardt, K., Radical Ligands Confer Nobility on Base-Metal Catalysts. Science 2010, 327,794 - 795. (b) Blanchard, S.; Derat, D.; Desage-El Murr, M.; Fensterbank, L.; Malacria, M.; Mouriès-Mansuy, V., Non-Innocent Ligands: New Opportunities in Iron CatalysisEur. J. Inorg. Chem. 2012, 376 - 389.

(9) (a) Chu, T.; Belding, L.; Poddutoori, P. K.; van der Est, A.; Dudding, T.; Korobkov, I.; Nikonov, G. I., Unique molecular geometries of reduced 4and 5-coordinate zinc complexes stabilised by diiminopyridine ligand. Dalton Trans. 2016, 45, 13440 - 13448. (b) Myers, T. W.; Sherbow, T. J.; Fettinger, J. C.; Berben, L. A., Synthesis and characterization of bis(imino)pyridine complexes of divalent $\mathrm{Mg}$ and $\mathrm{Zn}$. Dalton Trans. 2016, 45, 5989 - 5998. (c) Scott, J.; Gambarotta, S.; Korobkov, I.; Knijnenburg, Q.; de Bruin, B.; Budzelaar, P. H. M., Formation of a Paramagnetic Al Complex and Extrusion of Fe during the Reaction of (Diiminepyridine)Fe with AlR3 $(\mathrm{R}=\mathrm{Me}, \mathrm{Et})$. J. Am. Chem. Soc. 2005, 127, 17204-17206.

(10) Berben, L. A., Catalysis by Aluminum(III) Complexes of Non-Innocent Ligands. Chem. Eur. J. 2015, 21, 2724 - 2742. 
(11) Myers, T. W.; Berben, L. A., Aluminum-Ligand Cooperative N-H Bond Activation and an Example of Dehydrogenative Coupling. J. Am. Chem. Soc. 2013, 135, 9988-9990.

(12) Myers, T. W.; Berben, L. A., Aluminium-ligand cooperation promotes selective dehydrogenation of formic acid to $\mathrm{H}_{2}$ and $\mathrm{CO}_{2}$. Chem. Sci. 2014, 5, 2771-2777.

(13) Sherbow, T. J.; Fettinger, J. C.; Berben, L. A., Control of Ligand pKa Values Tunes the Electrocatalytic Dihydrogen Evolution Mechanism in a Redox-Active Aluminum(III) Complex. Inorg. Chem. 2017, 56, 8651-8660.

(14) Sherbow, T. J.; Carr, C. R.; Saisu, T.; Fettinger, J. C.; Berben, L. A., Insight into Varied Reaction Pathways for $\mathrm{O}-\mathrm{H}$ and $\mathrm{N}-\mathrm{H}$ Bond Activation by Bis(imino)pyridine Complexes of $\mathrm{Al}(\mathrm{III})$. Organometallics 2016, 35, 9 14.

(15) Sugiyama, H.; Aharonian, G.; Gambarotta, S.; Yap, G. P. A.; Budzelaar, P. H. M., Participation of the $\alpha, a^{c}$-Diiminopyridine Ligand System in Reduction of the Metal Center during Alkylation J. Am. Chem. Soc. 2002, 124, 12268-12274.

(16) (a) Campora, J.; Perez, C. M.; Rodriguez-Delgado, A.; Naz, A. M.; Palma, P.; Alvarez, E., Selective alkylation of 2,6-diiminopyridine ligands by dialkylmanganese reagents: A "One-Pot" synthetic methodology. Organometallics 2007, 26, 1104-1107. b) Pérez, C. M.; Rodríguez-Delgado, A.; Palma, P.; Álvarez, E.; Gutiérrez-Puebla, E.; Cámpora, J., Neutral and Cationic Alkylmanganese(II) Complexes Containing 2,6-Bisiminopyridine Ligands Chem. Eur. J.2010, 16, 13834-13842.

(17) Sandoval, J. J.; Melero, C.; Palma, P.; Álvarez, E.; Rodríguez-Delgado, A.; Cámpora, J., Oxygen-Induced Dimerization of Alkyl-Manganese(II) 2,6-Bisiminopyridine Complexes: Selective Synthesis of a New Ditopic NNN-Pincer Ligand. Organometallics 2016, 35, 3336 - 3343.

(18) (a) Knijnenburg, Q.; Smits, J. M. M.; Budzelaar, P. H. M., Reaction of the Diimine Pyridine Ligand with Aluminum Alkyls: An Unexpectedly Complex Reaction. Organometallics 2006, 25, 1036-1046. (b) Knijnenburg, Q.; Smits, J. M. M.; Budzelaar, P. H. M., Reaction of AlEt2Cl with the diiminepyridine ligand: an unexpected product. C. R. Chimie 2004, 2004, $865-869$.

(19) Blackmore, I. J.; Gibson, V. C.; Hitchcock, P. B.; Rees, C. W.; Williams, D. J.; White, A. J. P., Pyridine n-alkylation by lithium, magnesium, and zinc alkyl reagents: Synthetic, structural, and mechanistic studies on the bis(imino)pyridine system. J. Am. Chem. Soc. 2005, 127, 6012 - 6020.

(20) Arrowsmith, M.; Hill, M. S.; Kociok-Köhn, G., Dearomatization and $\mathrm{C}-\mathrm{H}$ Deprotonation with Heavier Group 2 Alkyls: Does Size Matter? Organometallics 2010, 29, 4203-4206.

(21) Sandoval, J. J.; Palma, P.; Álvarez, E.; Cámpora, J.; Rodríguez-Delgado, A., Mechanism of Alkyl Migration in Diorganomagnesium 2,6Bis(imino)pyridine Complexes: Formation of Grignard-Type Complexes with Square-Planar Mg(II) Centers Organometallics 2016, 35, 3197 - 3204.

(22) Sandoval, J. J.; Palma, P.; Álvarez, E.; Rodríguez-Delgado, A.; Cámpora, J., Dibenzyl and diallyl 2,6-bisiminopyridinezinc(II) complexes: selective alkyl migration to the pyridine ring leads to remarkably stable dihydropyridinates Chem. Commun. 2013, 49, 6791 - 6793.

(23) More recently, we observed that the reaction of dibenzylzinc with the less hindered BIP derivative that bears mesityl substituents at the imino $\mathrm{N}$ atom ( $\left.{ }^{\mathrm{Mes}} \mathrm{BIP}\right)$ is also fully selective, affording the mesityl analogue of $\mathbf{1}$ as the only observed product. The new dihydropyridinate complex was isolated in ca. $70 \%$ yield as a analytically pure microcrystalline solid. Like 1 , it is thermally very stable but very sensitive to moisture traces.

(24) (a) Pollak, N.; Christian, D.; Ziegler, M. The Power to Reduce: Pyridine Nucleotides - Small Molecules with a Multitude of Functions. Biochem.J. 2007, 402, 205-218. b) Houtkooper, R. H.; Cantó, C.; Wanders, R. J.; Auwerx, J., The Secret Life of NAD(+): An Old Metabolite Controlling New Metabolic Signaling Pathways. Endocrin. Rev. 2010, 31, 194-223.

(25) Dolega, A. Alcohol Dehydrogenase and its simple inorganic models. Coord. Chem. Rev. 2010, 254, 916-937.

(26) Kumar Padhi, S; Fukuda, R.; Ehra, M.; Tanaka, K. Comparative Study of $\mathrm{C} \wedge \mathrm{N}$ and $\mathrm{N} \wedge \mathrm{C}$ Type Cyclometalated Ruthenium Complexes with a NAD+/NADH Function. Inorg. Chem. 2012, 51, 8091 - 8102.

(27) (a) Chen, Q.-A.; Gao, K.; Duan, Y.; Zhi-Shi, Y.; Shi, L.; Yang, Y.; Zhou, Y. G., Dihydrophenanthridine: A New and Easily Regenerable $\mathrm{NAD}(\mathrm{P}) \mathrm{H}$ Model for Biomimetic Asymmetric Hydrogenation J. Am.
Chem. Soc. 2012, 134, 2442-2448. (b) Gutierrez-Bonet, A.; Tellis, J. C.; Matsui, J. K.; Vara, B. A.; Molander, G. A., 1,4-Dihydropyridines as Alkyl Radical Precursors: Introducing the Aldehyde Feedstock to Nickel/Photoredox Dual Catalysis . ACS Catal. 2016, 6, 8004-8008.

(28) McSkimming, A.; Colbran, S. B., The coordination chemistry of organo-hydride donors: new prospects for efficient multi-electron reduction. Chem. Soc. Rev. 2013, 42, 5439 - 5488.

(29) Walker, D.; Woodman, T. J.; Schorman, M.; Hughes, D. L.; Bochmann, M., Synthesis, Structures, and Ring-Opening Polymerization Reactions of Substituted Cyclopentadienyl Complexes of Zinc Organometallics 2003, 22, 797-803.

(30) (a) Piers, W. E., The Chemistry of Perfluoroaryl Boranes Adv. Organomet. Chem. 2005, 52, 1-76. (b) Erker, G., Tris(pentafluorophenyl)borane: a special boron Lewis acid for special reactions. Dalton Trans. 2005, 1883-1890. (c) Piers, W. E.; Chivers, T., Pentafluorophenylboranes: from obscurity to applications. Chem. Soc. Rev. 1997, 26, 345-354.

(31) Chen, E. X.; Marks, T. J., Cocatalysts for Metal-Catalyzed Olefin Polymerization: Activators, Activation, Processes, and Structure-Activity Relationships. Chem. Rev. 2000, 100, 1391-1434.

(32) (a) Tondreau, A. M.; Milsmann, C.; Patrick, A. D.; Hoyt, H. M.; Lobkovsky, E.; Wieghardt, K.; Chirik, P. J., Synthesis and Electronic Structure of Cationic, Neutral, and Anionic Bis(imino)pyridine Iron Alkyl Complexes: Evaluation of Redox Activity in Single-Component Ethylene Polymerization Catalysts. J. Am. Chem. Soc. 2010, 132, 15046 - 15059. (b) Bouwkamp, M. W.; Lobkovsky E.; Chirik, P. J., Bis(imino)pyridine Iron(II) Alkyl Cations for Olefin Polymerization. J. Am. Chem. Soc. 2006, 127, 9660 $-9661$.

(33) Hannant, M. D.; Schormann, M.; Bochmann, M., Synthesis and catalytic activity of three-coordinate zinc cations J. Chem. Soc., Dalton Trans., 2002, 4071 - 4073.

(34) Vahrenkamp, H., Why does nature use zinc-a personal view. Dalton Trans., 2007, 4741-4759.

(35) Note that classic zinc alkyls are amongst the earliest examples of artificial organometallic compounds, and utterly alien to biological chemistry. For a descriptive account of the properties and historical aspects of these compounds, see: Seyferth, D., Zinc Alkyls, Edward Frankland, and the Beginnings of Main-Group Organometallic Chemistry Organometallics, 2001, 20, $2940-2955$.

(36) Vance, A. L.; Alcock, N. W.; Heppert, J. A.; Busch, D. H., An Octahedral Template Based on a New Molecular Turn: Synthesis and Structure of a Model Complex and a Reactive, Diphenolic Ligand and Its Metal Complexes. Inorg. Chem. 1998, 37, 6912 - 6920.

(37) (a) Bart, S. C.; Chopek, K.; Bowkamp, M. W.; Lobkovsky, E.; Neese, F.; Weighardt, K.; Chirik, P. J., Electronic Structure of Bis(imino)pyridine Iron Dichloride, Monochloride, and Neutral Ligand Complexes: A Combined Structural, Spectroscopic, and Computational Study. J. Am. Chem. Soc. 2006, 128, 13901-13912. (b) Rahimi, N.; de Bruin, B.; Budzelaar, P. H. M., Balance between Metal and Ligand Reduction in Diiminepyridine Complexes of Ti. Organometallics, 2017, 36, 3189-3198.

(38) Okuniewski, A.; Rosiak, D.; Chojnacki, J.; Becker, B., Coordination polymers and molecular structures among complexes of mercury(II) halides with selected 1-benzoylthioureas. Polyhedron, 2015, 90, 47 - 57.

(39) Reardon, D.; Aharonian, G.; Gambarotta, S.; Yap, G. P. A., Monoand Zerovalent Manganese Alkyl Complexes Supported by the $\alpha, \alpha$ '-Diiminato Pyridine Ligand: Alkyl Stabilization at the Expense of Catalytic Performance Organometallics, 2002, 21, 786 - 788.

(40) (a) Cartes, M. A.; Rodríguez-Delgado, A.; Palma, P. Álvarez, E.; Cámpora, J., Sequential Reduction and Alkyl Exchange Reactions of Bis(imino)pyridine Dialkyliron(II) with Trimethylaluminum. Organometallics, 2014, 33, 1834 - 1839.

(41) Fernández, I.; Trovitch, R. J.; Lobkovsky, E.; Chirik, P. J., Synthesis of Bis(imino)pyridine Iron Di- and Monoalkyl Complexes: Stability Differences between $\mathrm{FeCH}_{2} \mathrm{SiMe}_{3}$ and $\mathrm{FeCH}_{2} \mathrm{CMe}_{3}$ Derivatives. Organometallics, 2008, 27, 109 - 118.

(42) (a) Zhu, D.; Janssen, F. B. J.; Budzelaar, P. H. M., $(\mathrm{Py})_{2} \mathrm{Co}\left(\mathrm{CH} 2 \mathrm{SiMe}_{3}\right)_{2}$ As an Easily Accessible Source of "CoRe" Organometallics, 2010, 29, 1897. b) Kooistra, T. M.; Knijnenburg, Q.; Smits, J. M. M.; Horton, A. D.; Budzelaar, P. H. M.; Gal, A. W., Olefin Polymerization with 
[\{bis(imino)pyridyl $\left.\} \mathrm{Co}^{\mathrm{II}} \mathrm{Cl}_{2}\right]$ : Generation of the Active Species Involves Co. Angew. Chem. Int. Ed. 2001, 40, 4719 - 4722.

(43) (a) Bart, S. C.; Chopek, K.; Bill, E.; Bouwkamp, M. W.; Lobkovsky, E.; Neese, F.; Wieghardt, K.; Chirik, P. J., Electronic Structure of Bis(imino)pyridine Iron Dichloride, Monochloride, and Neutral Ligand Complexes: A Combined Structural, Spectroscopic, and Computational Study. J. Am. Chem. Soc. 2006, 128, 13901 - 13912. (b) Bouwkamp, M. W.; Bart, S. C.; Hawrelak, E. J.; Trovitch, R. J.; Lobkovsky, E.; Chirik, P.J., Square planar bis(imino)pyridine iron halide and alkyl complexes. Chem. Commun. 2005, 3406 - 3408. (c) Scott, J.; Gambarotta, S.; Korobkov, I.; Budzelaar, P. H. M., Reduction of (Diiminopyridine)iron: Evidence for a Noncationic Polymerization Pathway? Organometallics 2005, 24, 6298 6300.

(44) Knijnenbug, Q.; Hetterscheid, D.; Kooistra, T. M.; Budzelaar, P. H. M., The Electronic Structure of (Diiminopyridine)cobalt(I) Complexes Eur. J. Inorg. Chem. 2004, 1204 - 1211.

(45) Zhu, D.; Thapa, I.; Gambarotta, S.; Budzelaar, P. H. M., Redox-Active Ligands and Organic Radical Chemistry. Inorg. Chem. 2011, 50, 9879 9887.

(46) (a) Cheung, P. M.; Berger, P.; Zakharov, L. N.; Gilbertson, J. D., Square planar $\mathrm{Cu}(\mathrm{I})$ stabilized by a pyridinediimine ligand. Chem. Commun. 2016, 52, 4156 - 4159. (b) Le Gall, B.; Conan, F.; Cosquer, N.; Kerbaol, J. M. Kubicki, M. M.; Vigier, E.; Le Mest, Y. Sala Pala, J., Unexpected behaviour of copper(I) towards a tridentate Schiff base: synthesis, structure and properties of new $\mathrm{Cu}(\mathrm{I})-\mathrm{Cu}(\mathrm{II})$ and $\mathrm{Cu}$ (II) complexes Inorg. Chim. Acta 2001, 324, 300 - 308.

(47) Jurca, T.; Ouanounou, S.; Shih, W.-C.; Ong, T.-G.; Yap, G. P. A.; Korobkov, I.; Gorlesky, S. Richeson, D., Structural and electronic trends for five coordinate 1st row transition metal complexes: $\mathrm{Mn}$ (II) to $\mathrm{Zn}$ (II) captured in a bis(iminopyridine) framework Dalton Trans. 2016, 45, 14327 . 14334.

(48) Kundu, S.; Brennessel, W. W.; Jones. W. D., Synthesis and Reactivity of New Ni, Pd, and Pt 2,6-Bis(di-tert-butylphosphinito)pyridine Pincer Complexes. Inorg. Chem., 2011, 50, 9443 - 9445.

(49) Fulmer, G. R.; Miller, A. J.M.; Sherden, N. H.; Gottlieb, H. E.; Nudelman, A.; Stoltz, A. B. M.; Bercaw, J. E.; Goldberg, K. I., NMR Chemical Shifts of Trace Impurities: Common Laboratory Solvents, Organics, and Gases in Deuterated Solvents Relevant to the Organometallic Chemist. Organometallics, 2010, 29, 2176 - 2179.

(50) Scott, J.; Vidyratne, I.; Korobkov, I.; Budzelaar, P. H. M., Multiple Pathways for Dinitrogen Activation during the Reduction of an $\mathrm{Fe}$ Bis(iminepyridine) Complex Inorg. Chem., 2008, 47, 896 - 911.

(51) Wiegand, A.-K.; Rit, A.; Okuda, J., Molecular Zinc Hydrides Coord. Chem. Rev., 2016, 314, 71 - 82.

(52) Rit, A.; Spaniol, T. P.; Maron, L.; Okuda, J., Mixed Alkyl Hydrido Complexes of Zinc: Synthesis, Structure, and Reactivity. Organometallics, 2014, 33, 2039 - 2047.

(53) Brookhart, M.; Grant, A. F.; Volpe, A. F., $\left[\left(3,5-\left(\mathrm{CF}_{3}\right)_{2} \mathrm{C}_{6} \mathrm{H}_{3}\right)_{4} \mathrm{~B}\right]-$ $\left[\mathrm{H}\left(\mathrm{OEt}_{2}\right)_{2}\right]^{+}$: a convenient reagent for generation and stabilization of cationic, highly electrophilic organometallic complexes. Organometallics, 1992, 11,3920 - 3922.

54) Bruker APEX2; Bruker AXS, Inc.; Madison, WI, 2007.

55) Bruker Advanced X-ray solutions. SAINT and $S A D A B S$ programs. Bruker AXS Inc. Madison, WI, 2004.

56) Burla, M. C.; Camalli, M.; Carrozzini, B.; Cacarano, G. L.; Giacovazzo, C.; Polidori, G.; Spagna, R., SIR2002: the Program. J. Appl. Crystallogr. 2003, 36, $1103-1104$.

57) Spek, A. L., Single-crystal structure validation with the program PLATON. J. Appl. Crystallogr., 2003, 36, 7-13

58) van der Sluis, P.; Spek, A. L., BYPASS: an effective method for the refinement of crystal structures containing disordered solvent regions. Acta Crystallogr., Sect. A. 1990, 46, 194-201. 


\section{For TOC Only:}

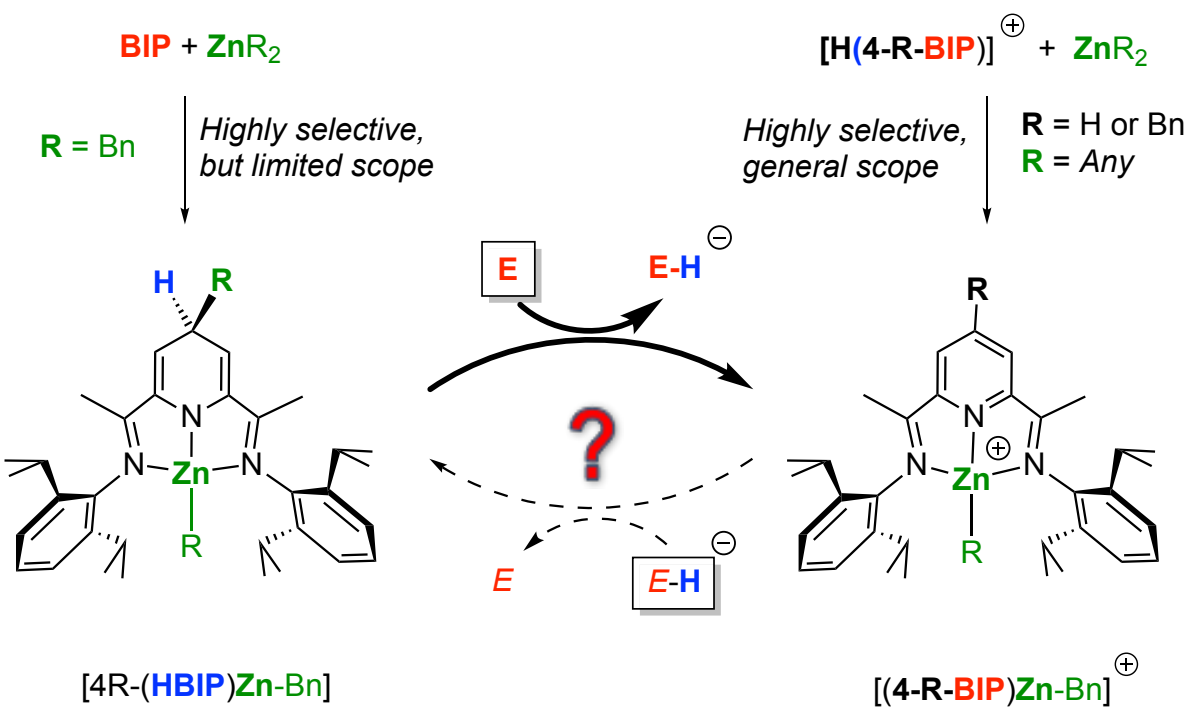

Stable $\sigma$-organozinc(II)-1,4-dihydropyridinates behave as ligand-based hydride transfer complexes, rather than as typical organometallic nucleophiles, but the reverse process has not been observed. 